\title{
AVRUPA TOPLULUĞUNUN LA HAYE MILLETLERARASI ÖZEL HUKUK KONFERANSINA ÜYELİĞİ
}

\author{
Membership of the European Community in the Hague \\ Conference on Private International Law
}

\section{Dr. Gülüm BAYRAKTAROĞLU ÖZÇELIK*}

I-Giriş II- Avrupa Topluluğunun La Haye Milletlerarası Özel Hukuk Konferansına Üyeliğinin Yasal Temeli A) Kurucu Antlaşma Hükümleri Uyarınca Avrupa Topluluğunun Uluslararası Örgütlere Üyeliği B) Avrupa Topluluğunun Milletlerarası Özel Hukuk Alanındaki Yetkisinin Niteliği ve Kapsamı III- Avrupa Topluluğunun La Haye Konferansına Üyeliğinin Kurumsal Çerçevesi A) Avrupa Topluluğu ile La Haye Konferans1 Arasındaki İliş̧ilerin Gelişimi B) La Haye Konferansı Üyesi Olarak Avrupa Topluluğunun Hak ve Yükümlülükleri 1- Avrupa Topluluğu ile Topluluğa Üye Ülkeler Arasındaki Yetki Paylaşımı ve Avrupa Topluluğunun Yetki Bildirisi 2- Üyelik Haklarının Kullanımı 3- Malî Yükümlülükler IVÜyeliğin La Haye Sözleşmeleri Üzerindeki Etkisi V-Sonuç

\section{ÖZET}

Avrupa Topluluğunun 2007 yılında gerçekleşen La Haye Milletlerarası Özel Hukuk Konferansına üyeliği, her iki örgüt bakımından da önemli bir gelişmeyi işaret eder. Bu şekilde Topluluk, milletlerarası özel hukuk alanındaki dış yetkisini kullanmak suretiyle milletlerarası özel hukukun yeknesaklaştırılmasına hizmet eden en önemli örgütlerden birinde söz sahibi olmuştur. La Haye Konferansı bakımından ise, söz konusu üyeliğin gündeme gelmesi, Konferans statüsünün değiştirilmesi zorunluluğunu doğurmuş, değişiklikler neticesinde Konferans, sadece devletlerin değil aynı zamanda

* Ankara Üniversitesi Hukuk Fakültesi Avrupa Birliği Hukuku Anabilim Dalı Araştırma Görevlisi. 
uluslararası örgütlerin de üyeliğine imkân tanıyan Statüsüyle yeni bir döneme girmiştir.

Anahtar Kelimeler: Avrupa Topluluğu, La Haye Konferansı, La Haye Sözleşmesi, milletlerarası özel hukuk, dış yetki, münhasır yetki, Lugano görüşü

\section{ABSTRACT}

Accession of the European Community to the Hague Conference on Private International Law in 2007 marks an important development for both organisations. By way of membership, the European Community has fully participated in the work of a leading international organisation in the field of harmonization of private international law. For the Hague Conference, membership of the European Community necessiated revision of its Statue which opened the Conference to membership of international organisations besides states and started a new phase in the history of the Conference.

Keywords: European Community, Hague Conference, private international law, external competence, exclusive competence, Lugano opinion

\section{I- Giriş ${ }^{* *}$}

Avrupa Topluluğunun (AT) son y1llarda en aktif olduğu alanlardan birini milletlerarası özel hukuk oluşturmaktadır. 1999 yılında yürürlüğe giren Amsterdam Antlaşmasında Topluluğun milletlerarası özel hukuk alanında yetkili kılınması ile birlikte, bir yandan bu alana ilişkin Topluluk tasarruflarının sayısı hızla artarken, diğer yandan öğretide tartışmalar söz konusu yetkinin niteliği ve kapsamı üzerine yoğunlaşmıştır. Son birkaç yılda ise, söz konusu tartışmaların merkezinde, Topluluğun bu alandaki dış yetkisi (external competence) yer almıştır. Özellikle birbiri ardına gelen iki gelişmenin söz konusu tartışmalara yön verdiği söylenebilir: İlk olarak 2002 yılında, Hukukî ve Ticarî Konularda Yargı Yetkisi ve Yargı Kararlarının Tenfizine Dair 16 Eylül 1988 tarihli Lugano Konvansiyonunun ${ }^{1}$ gözden

\footnotetext{
** Bu çalışmada kullanılan kısaltmalar şu şekildedir: aşa.: aşağıda; bkz.: bakınız; C: Cilt; CJEL: Columbia Journal of European Law; CMLR: Common Market Law Review, dn.: dipnot; ECR: European Court Reports; Ed.: Edition, ed(s): editor (s); EFAR: European Foreign Affairs Review, EJLR: European Journal of Law Reform; ERPL: European Review of Private Law; f.: fıkra; I.: Issue; ICLQ: International and Comparative Law Quarterly; m.: madde; NILR: Netherlands International Law Review; O. J.: Official Journal; para.: paragraf; s.: sayfa; v.d.: ve devamı; Vol.: Volume; Y.: Year/Yıl; yuk.: yukarıda; YPIL: Yearbook of Private International Law.

${ }^{1}$ Convention of 16 September 1988 on Jurisdiction and the Enforcement of Judgments in Civil and Commercial Matters, O.J. 1988 L 319/9.
} 
geçirilerek değiştirilmesi sonucu ortaya çıkan "Yeni Lugano Konvansiyonu"nun ${ }^{2}$ akdi konusunda Topluluğun münhasıran yetkili olup olmadığı sorunu gündeme gelmiş, bu sorun, Avrupa Toplulukları Adalet Divanının $^{3}, 3$ Şubat 2006 tarihli görüşü ${ }^{4}$ ile açıklığa kavuşmuştur ${ }^{5}$. Tartışmalara yön veren ikinci gelişme ise, bu çalışmanın da konusunu oluşturan, AT’nin 2007 yılında gerçekleşen La Haye Milletlerarası Özel Hukuk Konferansına üyeliğidir ${ }^{6}$. Milletlerarası özel hukuk kurallarının yeknesaklaştırılması amacıyla 1893 yılından bu yana faaliyet gösteren ve bu alandaki en önemli uluslararası örgütlerden biri olarak kabul edilen La Haye Konferansına üyeliği, Topluluğun milletlerarası özel hukuk alanında sahip olduğu dış yetkinin bir sonucu olarak ortaya çıkmıştır.

${ }^{2}$ Hukukî ve Ticarî Konularda Yargı Yetkisi ve Yargı Kararlarının Tenfizine Dair Lugano Konvansiyonunun yenilenmiş şekli, bu çalışmada, gerek Konvansiyonun adının uzun olması gerekse selefi 1988 tarihli Hukukî ve Ticarî Konularda Yargı Yetkisi ve Yargı Kararlarının Tenfizine Dair Lugano Konvansiyonu ile karıştırılmasının önüne geçmek amacıyla, "yeni Lugano Konvansiyonu" olarak anılmıştır. Yeni Lugano Konvansiyonu, 30 Ekim 2007 tarihinde Lugano'da, AT ile İsviçre, Norveç ve İzlanda arasında imzalanmıştır. Söz konusu Konvansiyonun metni için bkz. <http://www.bj.admin.ch/etc/medialib/data/ wirtschaft/ipr.Par.0022.File.tmp/20071030_entw_lugano_convention-e.pdf> (02.04.2008).

3 Avupa Toplulukları Adalet Divanı (Court of Justice of the European Communities), bu çalışmada kısaca "ATAD" ya da "Divan" olarak anılmıştır.

4 Opinion C-1/03 of 7 February 2006, <http://curia.europa.eu/jurisp/cgiin/form.pl?lang=en\&Submit=Submit\&alldocs=alldocs\&docj=docj\&amp;docop=docop\&do cor $=$ docor $\&$ docjo $=$ docjo $\&$ numaff $=$ Avis $+1 \% 2 \mathrm{~F} 03 \&$ datefs $=\&$ datefe $=\&$ nomusuel $=\&$ domain $\mathrm{e}=\& \operatorname{mots}=\& \operatorname{resmax}=100>$ (29.02.2008). Divan'1n söz konusu görüșü, bu çalıșmada "Lugano Görüşü" olarak anılmıştır.

${ }^{5}$ Söz konusu görüşe dair değerlendirmeler için bkz. BAYRAKTAROĞLU ÖZÇELİK, G.: Avrupa Topluluğunun Milletlerarası Özel Hukuk Alanında Uluslararası Anlaşma Akdetme Yetkisi ve C-01/03 sayılı ve 7 Şubat 2006 Tarihli Avrupa Toplulukları Adalet Divanı Görüșü, AÜHFD, Y. 2008, C. 57, S. 2, s. 17- 49; BORRÁS, A.: "Competence of the Community to Conclude the Revised Lugano Convention on Jurisdiction and the Recognition and Enforcement of Judgments in Civil and Commercial Matters- Opinion C1/03 of February 2006: Comments and Immediate Consequences", YPIL, Y. 2006, Vol. 8, s. 37-52; LAVRANOS, N.: "Case Law: Opinion 1/03", CMLR, Y. 2006, Vol. 43, s. 10871100; BAUMÉ, T.: "Competence of the Community to Conclude the New Lugano Convention on Jurisdiction and Recognition and Enforcement of Judgements in Civil and Commercial Matters: Opinion 1/03 of 7 Feburary 2006", German Law Journal, Y. 2006, Vol. 7, I. 8, s. 681-692; POCAR, F. (ed.): The External Competence of the European Union and Private International Law, Proceedings of the Round Table held at Milan University on 16 September 2006, Milan 2007.

${ }^{6}$ La Haye Milletlerarası Özel Hukuk Konferansı hakkında bkz. 〈http://www.hcch.net> (29.02.2008); SCHULZ, A.: "Current Developments: The Accession of the European Community to the Hague Conference on Private International Law", ICLQ, Y. 2007, Vol. 56, s. 939; VAN LOON, H.: "Globalisation and the Hague Conference on Private International Law", International Law FORUM du droit international, Y. 2000, Vol. 2, s. 230-234; VAN LOON, H.: "Hague Conference on Private International Law", International Organization and Integration: Annotated Basic Documents and Descriptive Directory of International Organizations and Arrangements, (P. J. G. Kapteyn (ed.)), The Hague 1981, s. 9 vd. 
La Haye Konferansı, bugün altmış dokuzu bulan üye sayısıyla, uluslararası adlî ve idarî işbirliği; uygulanacak hukuk; mahkemelerin yetkisi ile yargı kararlarının tanınması ve tenfizine ilişkin pek çok konuda hazırladığı çok taraflı milletlerarası sözleşmeler (La Haye Sözleşmeleri) aracılığıyla milletlerarası özel hukukun yeknesaklaştırılmasına öncülük etmektedir ${ }^{7}$.

AT ile La Haye Konferansı arasındaki ilişkiler, Topluluğun kurulduğu 1957 yılından itibaren pek çok farklı uluslararası örgüt çatısı altında olduğu gibi, La Haye Konferansında da sahip olduğu gözlemci statüsü ile başlamış ve şekillenmiş, Amsterdam Antlaşması ile birlikte Topluluğun milletlerarası özel hukuk alanında yetkilendirilmesi sonucunda ise, Topluluğun Konferansa üyeliği gündeme gelmiştir. Avrupa Komisyonu, söz konusu üyeliğin, Topluluğa bir yandan Konferans içerisinde, uluslararası seviyede özel hukukta adlî işbirliği alanında sahip olduğu yeni role uygun bir statü kazandıracağını, diğer yandan ise, yetkili olduğu alanlarda $L a$ Haye Sözleşmelerinin müzakeresine tam katılımın önünü açarak, aynı konudaki Topluluk düzenlemeleri ile uluslararası düzenlemeler arasında tutarlılık sağlanmasına katkıda bulunacağını belirterek, üyelik başvurusunun siyasi ve hukukî gerekçelerini açıklamıştır ${ }^{8}$.

AT 2002 y1lında Konferansa üyelik için resmen başvurmuştur. Bununla birlikte, La Haye Konferansı, Statüsü uyarınca ancak devletlerin üyeliğine açık bir uluslararası örgüt olduğundan, söz konusu üyeliğin gerçekleşebilmesi için Konferansın 1955 yılından beri uygulanagelen Statüsü, değiştirilmek zorunda kalmıştır. Bu anlamda AT'nin üyeliğinin gerçekleşmesi amacıyla yapılan Statï değişikliği ile Konferansa devletlerin yanında uluslararası örgütlerin üyeliğinin de mümkün kılınmış olması, Konferans bakımından da yeni bir dönemin başlangıcını işaret etmektedir.

AT'nin La Haye Konferansına üyelik süreci ile söz konusu üyeliğin sonuçlarını açıklama amacını taşıyan bu çalışma, esas itibariyle üç bölüme ayrılmıştır. Öncelikle AT'nin La Haye Milletlerarası Özel Hukuk Konferansına üyeliğinin yasal temeli açıklanmıştır. Söz konusu başlık altında, Avrupa Topluluğunu Kuran Antlaşma ${ }^{9}$ hükümleri uyarınca Topluluğun uluslararası örgütlere üyeliğinin yasal temeli ile milletlerarası özel hukuk alanındaki yetkisinin niteliği ve kapsamı incelenmiștir. Takip eden bölümlerde ise sirasıyla, AT'nin La Haye Konferansına üyeliğinin

7 La Haye Konvansiyonları hakkında bkz. <http://hcch.e-vision.nl/index_en.php?act= conventions.listing> (29.02.2008); BAYRAKTAROĞLU, G.: "Harmonization of Private International Law At Different Levels: Communitarization v. International Harmonization", EJLR, Y. 2004, Vol. 5, I. 1/ 2, s. 150 vd.

${ }^{8}$ Proposal for a Council Decision on the accession of the European Community to the Hague Conference on Private International Law, COM (2005) 639 final.

9 Treaty Establishing the European Community, O.J. 2002 C325/33. Avrupa Topluluğunu Kuran Antlaşma, bu çalışmada kısaca "Kurucu Antlaşma" olarak anılmıştır. 
kurumsal çerçevesi ile üyeliğin $L a$ Haye Sözleşmeleri bakımından sonuçlarına yer verilmiştir. Çalışma, sonuç bölümüyle tamamlanmıştır.

\section{II- Avrupa Topluluğunun La Haye Milletlerarası Özel Hukuk Konferansına Üyeliğinin Yasal Temeli}

AT'nin La Haye Konferansına üyeliğinin yasal temelinin tayini, biri genel diğeri özel nitelikte iki sorunun cevaplandırılmasını gerektirir. İlk soru, Kurucu Antlaşmanın Topluluğun uluslararası örgütlere üyeliğini düzenleyip düzenlemediğine ilişkindir. $\mathrm{Bu}$ husus, kuşkusuz, Topluluğun La Haye Konferansına üyeliğgi ile sınırlı değildir. Cevaplandırılması gereken ikinci soru ise, La Haye Konferansının faaliyet alanı bakımından Topluluğun dış yetkisinin bulunup bulunmadığıdır. Zira, Topluluğun bir uluslararası örgüte üye olabilmesi için, söz konusu örgütün faaliyet alanı bakımından yetkili olmasi gerekmektedir.

Hemen belirtmek gerekir ki, AT'nin bir uluslararası örgüte üye olabilmesi için Topluluk hukuku bakımından gerçekleşmesi gerekli yasal şartlar yerine gelmiş olsa dahi, üyeliğin gerçekleşebilmesi için, söz konusu uluslararası örgüte ilişkin düzenlemelerin de buna imkân tanıması gereklidir. Dolayısıyla, Topluluk hukuku bakımından üyelik şartlarının gerçekleşmiş olması, her zaman üyeliğin de gerçekleşeceği şeklinde anlaşılmamalıdır ${ }^{10}$.

\section{A) Kurucu Antlaşma Hükümleri Uyarınca Avrupa Topluluğunun Uluslararası Örgütlere Üyeliği}

AT'nin uluslararası örgütlere üyeliğinin yasal temeli tespit edilirken, esas itibariyle iki farklı üyelik şekli birbirinden ayrılmaktadır ${ }^{11}$ : Topluluğun, taraf olduğu bir uluslararası anlaşmanın (tarafları arasında) kurduğu bir örgütsel yapıya katılımı mümkün olduğu gibi, bağımsız bir yapıya sahip ve kendine özgü üyelik kuralları mevcut bir uluslararası örgüte üye olması da mümkündür ${ }^{12}$.

AT'nin taraf olduğu bir uluslararası anlaşma vasıtasıyla bir uluslararası örgütün kurucu üyesi olabilmesinin kaynağı, Ren- Moselle nehirleri üzerinde

\footnotetext{
${ }^{10}$ Bkz. așa. dn. 38 .

${ }^{11}$ Söz konusu ayrım hakkında bkz. SACK, J.: "The European Community's Membership of International Organizations", CMLR, Y. 1995, Vol. 32, s. 1229, 1238 vd.; GOVAERE, I./ CAPIAU, J./ VERMEERSCH, A.: "In- Between Seats: The Participation of the European Union in International Organizations", EFAR, Y. 2004, Vol. 9, s. 156; EECHOUT, P: External Relations of the European Union- Legal and Constitutional Foundations, Oxford 2006, s. 200.

12 AT’nin uluslararası örgütlere üyeliği konusunda bkz. EECKHOUT, s. 199 vd.; FRID, R.: The Relations Between the EC and International Organisations- Legal Theory and Practice, The Hague, London, Boston 1995, s. 119 vd.; MACLEOD, I./ HENDRY, I. D./ HYETT, S.: The External Relations of the European Communities, Oxford 1996, s. 163 vd.
} 
yapılan taşımacılı̆̆ın düzenlenmesine dair uluslararası anlaşmanın ${ }^{13}$ akdedilmesi konusundaki 1/76 sayılı ATAD görüşü olarak kabul edilmektedir ${ }^{14}$. Anılan görüşün 5. paragrafında Divan, "Topluluğun sadece üçüncü devletlerle anlaşma yapmak konusunda değil, aynı zamanda söz konusu devletlerle işbirliği yapmak suretiyle bir örgütün kurulmasina katılabilmek konusunda da yetkili olduğunu" ifade etmiştir. ATAD'ın, ortak taşımacılık politikasına ilişkin Kurucu Antlaşmanın 75. maddesinin 1. fikrasının (c) bendini yorumlarken yer verdiği bu ifade, Kurucu Antlaşmanın 300. maddesinde, söz konusu anlaşmalar bakımından geçerli olacak yasama usûlünün belirlenmesiyle kabul edilmiştir. Anılan maddenin 3. fikrasında, (diğer hususların yanı sıra) tarafları arasında işbirliği yoluyla özel kurumsal bir yapı kurmak amacıyla yapılan uluslararası anlaşmaların onay (assent) usûlüne tâbi olduğu hükme bağlanmıştır.

AT'nin bir uluslararası sözleşmeye taraf olmak suretiyle yeni bir örgütün kurulmasına katılması, çok sık tercih edilen bir yöntemdir. Burada kurulan söz konusu örgüt, taraflar arasında yapılmış olan sözleşmenin uygulanmasına dair bazı hususların tartışılması amacıyla oluşturulmuş bir platformdan ibaret olabileceği gibi, kalabalık bir idari yapıya sahip bir örgüt şeklinde de ortaya çıkabilmektedir ${ }^{15}$. Bu gruba örnek olarak Topluluğun Kuzeybatı Atlantik Balıkçılık Örgütü ${ }^{16}$, Kuzey Doğu Atlantik Balıkçılık Örgütü̈ $^{17}$, Kuzey Atlantik Somon Koruma Örgütü ${ }^{18}$ gibi balıkçllığa ve Uluslararası Zeytin Yağı Konseyi ${ }^{19}$ ile Uluslararası Şeker Konseyi ${ }^{20}$ gibi tarıma ilişkin örgütlerdeki üyelikleri örnek olarak verilebilir ${ }^{21}$.

Bununla birlikte, AT'nin La Haye Konferansına üyeliğinde olduğu gibi, mevcut bir uluslararası örgüte katılımı, bir uluslararası anlaşmaya taraf olmak suretiyle uluslararası bir örgütün kurulmasına katılımından farklıdır. Topluluğun bu şekilde mevcut bir uluslararası örgüte katılımı çok sık karşılaşılan bir durum değildir. Bunun en önemli hukukî sebebi, geleneksel olarak uluslararası örgütlerin ancak devletlerin katılımına imkân tanımasıdır ${ }^{22}$. Böyle bir durumda, Topluluğun üyeliğinin gerçekleşebilmesi

${ }^{13}$ Agreement on the Establishment of a European Laying up Fund for Inland Waterway Vessels.

${ }^{14}$ Opinion 1/76 (European Laying-up Fund for Inland Waterway Vessels) [1977] ECR 741.

${ }^{15}$ SACK, s. 1239.

${ }^{16}$ North-West Atlantic Fisheries Organization (NAFO), O.J. 1978 L 378/2.

${ }^{17}$ North-East Atlantic Fisheries Organization (NEAFC), O.J. 1981 L 227/22.

${ }^{18}$ North Atlantic Solmon Conservation Organization (NASCO), O.J. 1982 L 378/25.

${ }^{19}$ The International Olive Oil Council, O.J. 1987 L 214/1.

${ }^{20}$ International Sugar Council, O.J. 1991, L 379/ 15.

${ }^{21}$ SACK, s. 1240; FRID, s. 155.

22 AT'nin mevcut uluslararası örgütlere üyeliği önündeki siyasî engeller ise, Topluluğa üye ülkelerin ya da uluslararası örgüte üye olan üçüncü ülkelerin tutumlarından kaynaklanabilmektedir. Topluluğa üye ülkeler, gerek uluslararası örgütlere katılım konusunu egemenlik haklarının bir parçası olarak görmeleri, gerekse üye oldukları 
için, öncelikle söz konusu örgütün statüsünde değişiklik yapılarak, devletlerin yanında örgütlerin de katılımına imkân sağlanması gerekmektedir. Bu durumun iki örneğini, Birleşmiş Milletlere Bağlı Gıda ve Tarım Örgütü (FAO) $)^{23}$ ile La Haye Konferansı teşkil eder. Topluluğun her iki örgüte üyelik başvurusunun akabinde, statülerinde gerekli değişiklikler yapılarak, devletlerle birlikte bölgesel ekonomik örgütlerin de katılımına imkân tanınmış ve Topluluğun üyeliği ancak bu şekilde mümkün olabilmiştir. Topluluğun FAO ve La Haye Konferansı üyeliği dışında Avrupa İmar ve Kalkınma Bankası ${ }^{24}$ ve Dünya Ticaret Örgütii (DTÖ)'ne ${ }^{25}$ üyelikleri de AT'nin mevcut bir uluslararası örgüte üyeliğinin diğer örneklerini teşkil etmektedir ${ }^{26}$.

Topluluğun mevcut uluslararası örgütlere katılımı konusunda Kurucu Antlaşmada herhangi bir hükme yer verilmemekle birlikte, bunu engelleyen bir hüküm de mevcut değildir. Ancak Antlaşmanın çeşitli hükümlerinde, Topluluk ile uluslararası örgütler arasındaki ilişkilerin sürdürülmesi ve işbirliğinin geliştirilmesine dair düzenlemeler yer almaktadır. Örneğin, Antlaşmanın 302. maddesinde, Birleşmiş Milletler organları ve uzman kuruluşları (f.1) ile bütün uluslararası örgütlerle ilişkilerin sürdürülmesi (f.2) konusunda Komisyon yetkilendirilmiş; 303. ve 304. maddelerde ise, sırasıyla, Avrupa Konseyi ve Ekonomik İşbirliği ve Kalkınma Teşkilatı ${ }^{27}$ ile işbirliği yapılmasına dair hükümlere yer verilmiştir. Ayrıca, Antlaşmada eğitim (m. 149 (3)), kültür (m. 151(3)), kamu sağlığı (m. 152 (3)) ve çevre (m. 174 (4)) gibi bazı alanlarda da uluslararası örgütlerle ilişkilerin geliştirilmesine dair özel hükümler yer almıştır.

AT'nin mevcut uluslararası örgütlere üyeliği konusunda Kurucu Antlaşmada bir hükme yer verilmemiş olması karşısında, en azından bu konuda bir düzenleme yapılıncaya kadar, yasal temel olarak hangi hüküm ya da hükümlerin kabul edilmesi gerektiği konusunda, iki farklı görüş dile getirilmiştir. İlk görüş taraftarları, Antlaşmanın yukarıda anılan 300.

uluslararası örgüt içerisinde kendi etkilerini azaltmamak amacıyla, AT'nin üyeliğine muhalif kalabilmektedirler. Üçüncü ülkeler ise, Topluluk ile Topluluğa üye ülkeler arasındaki yetki paylaşımının uluslararası örgüt içerisinde özellikle oy hakkının kullanımı bakımından problem yaratabileceği ve Topluluğun katılımı ile birlikte örgüt içerisinde kendilerine karşı bir gruplaşma oluşabileceği endişesi taşıyabilmektedirler. Topluluğun uluslararası örgütlere katılımı önündeki siyasî engeller hakkında bkz.: EECHOUT, s. 200201; SACK, s. 1233.

${ }^{23}$ The Food and Agriculture Organisation. AT'nin FAO'ya üyeliği hakkında bkz. FRID, s. 229 vd.; MACLEOD/ HENDRY/ HYETT, s. 176 vd.

${ }^{24}$ European Bank for Reconstruction and Development (EBRD).

${ }^{25}$ World Trade Organisation (WTO). AT'nin DTÖ'ye üyeliği konusunda bkz. MACLEOD/ HENDRY/ HYETT, s. 179 vd.; LEAL-ARCAS, R.: "Polycephalous Anatomy of the EC in the WTO: An Analysis of Law and Practice”, FJIL, Y. 2007, Vol. 19, s. 570-670.

${ }^{26}$ SACK, s. 1238.

${ }^{27}$ Organization for Economic Cooperation and Development (OECD). 
maddesinin kıyasen uygulanmasını savunmaktadırlar ${ }^{28}$. Esas itibariyle bu hüküm, AT'nin üçüncü devletler ve uluslararası örgütlerle uluslararası anlaşma yapma usûlü ile birlikte ATAD'ın bu konudaki yetkisine ve söz konusu anlaşmaların Topluluk kurumları ve üye devletler bakımından bağlayıcılığına dair düzenleme getirmektedir ${ }^{29}$. Bu konudaki ikinci görüş ise, sadece Topluluğa belli bir alanda dış yetki (ister açık, zımnî nitelikte olsun) veren hükümlerin geniş olarak yorumlanması yoluyla, Topluluğun söz konusu alanda uluslararası örgütlere de üye olabileceği sonucuna varılabileceği yönündedir ${ }^{30}$.

Topluluğun La Haye Konferansına üyeliğinde ise, Topluluğun üyelik kararının alınması konusundaki yasama usûlü bakımından, Kurucu Antlaşmanın 300. maddesinin 2. fıkrasının 1. bendi ve aynı maddenin 3 . fıkrasının 2. bendi esas alınmış; Topluluğun La Haye Konferansının faaliyet alanını oluşturan milletlerarası özel hukuk alanındaki yetkisinin yasal dayanağı olarak ise, aşağıda incelenecek olan Kurucu Antlaşmanın 61. maddesinin (c) fikrası kabul edilmiştir. Antlaşmanın 300. maddenin 2. fıkrasının 1. bendi, uluslararası anlaşmaların imzalanması için, Komisyon tarafından hazırlanacak öneri üzerine, Konseyin kural olarak nitelikli oy çoğunluğu ile (ancak istisnaen söz konusu anlaşmanın oybirliği aranan alanlardan ya da 310. maddede belirtilen anlaşmalardan biri olması durumunda, oybirliği ile) karar alacağını; 300. maddenin 3. fıkrasının 2. bendi ise, Antlaşmanın 310. maddesinde düzenlenen anlaşmaların, özel bir örgüt kurmaya yönelik anlaşmaların, Topluluk bakımından önemli malî etkileri olacak anlaşmaların ve Antlaşmanın 251. maddesi uyarınca kabul edilmiş Topluluk tasarruflarında değişiklik gerektirecek anlaşmaların Parlamentonun onayına tâbi olacağını düzenlemektedir.

$\mathrm{Bu}$ anlamda, La Haye Konferansına üyelik için takip edilmesi gereken yasama usûlü, 9 Aralık 2005 tarihinde Komisyon önerisi ${ }^{31}$ ile başlamış, Avrupa Parlamentosunun 7 Eylül 2006 tarihli onayını takiben $^{32}$ AB Konseyinin 5 Ekim 2006 tarihli kararı ile son bulmuştur ${ }^{33}$.

${ }^{28}$ GOVAERE/ CAPIAU/ VERMEERSCH, s. 157; SACK, s. 1229-1232.

29 Antlaşmanın 300. maddesinde yer verilen yasama usûlünün, Topluluğun uluslararası örgütlere katılımında yarattığı problemler ve çözüm önerileri için bkz. GOVAERE/ CAPIAU/ VERMEERSCH, s. 157; SACK, s. 1229-1232.

${ }^{30}$ Bkz. FRID, s. 357 vd.

${ }^{31}$ Proposal for a Council Decision on the accession of the European Community to the Hague Conference on Private International Law, COM/2005/0639 final.

${ }^{32}$ European Parliament legislative resolution on the proposal for a Council decision on the accession of the European Community to the Hague Conference on Private International Law, P6_TA(2006)0345.

${ }^{33}$ Council Decision of 5 October 2006 on the accession of the Community to the Hague Conference on Private International Law, O.J. 2006 L 297/1. 


\section{B) Avrupa Topluluğunun Milletlerarası Özel Hukuk Alanındaki Yetkisinin Niteliği ve Kapsamı}

Topluluğun belli bir alanda dış yetkiye sahip olması, bu alanda üçüncü devletler ve uluslararası örgütlerle uluslararası anlaşma yapmasına imkân tanıdığı gibi, söz konusu alanda faaliyet gösteren uluslararası örgütlere üye olabilmesine de imkân tanımaktadır ${ }^{34}$.

Dış yetki, Kurucu Antlaşma ile ortak ticaret politikası, çevre, ekonomik, malî ve teknik işbirliği gibi sınırlı bazı alanlar bakımından açıkça tanınmıştır ${ }^{35}$. Açıkça tanınmadığı alanlarda ise, dış yetki, Kurucu Antlaşma hükümlerinden ya da ikincil düzenlemelerden zımnen de anlaşılabilir. Zımnî dış yetki kaynağını, ATAD'ın 1971 tarihinde verdiği ERTA kararında bulmaktadır ${ }^{36}$. Divan, söz konusu kararın 16. paragrafında, Topluluğun bir konudaki dış yetkisinin, "Topluluk hedeflerinden birinin gerçekleşmesi amactyla, Topluluğa iç yetki veren Antlaşma hükümleri ya da Antlaşma hükümlerine dayanılarak çıkarılmıs ikincil mevzuattan zımnen de doğabileceği" ifadesiyle kabul etmiş ve bu yaklaşımını sonraki tarihli kararlarında açıklayarak ve geliştirerek sıklıkla uygulamıştır ${ }^{37}$.

Topluluğun dış yetkisinin bulunduğu bir alanda faaliyet gösteren bir uluslararası örgüte üye olması, Topluluğun yanı sıra söz konusu örgüte üye olan AT üyesi devletlerin üyeliklerini, en azından her zaman etkilememektedir. Bu husus, Topluluğun söz konusu alandaki dış yetkisinin niteliği ile ilgilidir. Topluluğun münhasıran yetkili olduğu alanlarda, üye ülkelerin Topluluk lehine tüm yetkilerini terk ettikleri kabul edildiğinden, uluslararası düzeyde de Topluluğun tek başına hareket etme hakkı olduğu; dolayısıyla, münhasıran yetkili olduğu bir alanda faaliyet gösteren uluslararası örgütlere tek başına üye olması gerektiği kabul edilmektedir ${ }^{38}$.

${ }^{34}$ Topluluk hukukunda dış yetki kavramı için bkz. HARTLEY, T. C.: The Foundations of European Community Law, 6. Ed., Oxford 2007, s. 159 vd.; CRAIG, P./DE BÚRCA, G.: EU Law (Text, Cases and Materials), Oxford 2007, s. 168 vd.; MACLEOD/ HENDRY/ HYETT, s. 44 vd.; OKUTAN, G.: "Topluluğun ve Üye Ülkelerin Yetki Alanlarının Belirlenmesi”, Avrupa Birliği Hukuku (Gülören TEKİNALP/ Ünal TEKİNALP), İstanbul 2000, s. 85; VERWEY, D. R.: The European Community, The European Union and International Law of Treaties, Leiden 2004, s. $15 \mathrm{vd.}$

${ }^{35}$ Kurucu Antlaşmada dış yetkinin açıkça tanındığı alanlar hakkında bkz. VERWEY, s. 20- 21.

${ }^{36}$ Case 22/70 Commission v. Council (AETR/ERTA) [1971] ECR 263.

${ }^{37}$ Bkz. Joined Cases 3, 4 \& 6/76, Cornelis Kramer and others, [1976] ECR 1279; Opinion 1/76, [1977] ECR 741; Opinion 2/91, ILO, [1993] ECR I-1061; Opinion 1/92, [1992] ECR I-2821; Opinion 2/92, OECD II, [1995] ECR I-521; Opinion 1/94, WTO, [1994] ECR I5267.

${ }^{38}$ FRID, s. 361; MACLEOD/ HENDRY/ HYETT, s. 171. Topluluğun üye olduğu balıkçılık alanında çalışan örgütler bakımından durum bu şekildedir. Ayrıntılı açıklama için bkz. MACLEOD/ HENDRY/ HYETT, s. 171, 186. Bununla birlikte, Topluluğun bir alandaki dış yetkisi bulunsa ve hatta münhasır nitelikte olsa dahi, üyeliğin gerçekleşebilmesi için, söz konusu uluslararası örgütün statüsünün de buna imkân vermesi gerektiği bir kez daha hatırlatılmalıdır. Örneğin, sosyal politikalar bakımından dış yetkiye sahip olmasına ve 
Bununla birlikte, özellikle uluslararası örgütün faaliyet alanının geniş olması dolayısıyla Topluluğun üye olduğu uluslararası örgütün faaliyet alanının bütünü bakımından münhasıran yetkili olmaması durumunda, Topluluk ile birlikte üye ülkeler söz konusu örgütte birlikte üye sıfatını haiz olabilirler ${ }^{39}$. $\mathrm{Bu}$ durumda, uluslararası örgütün gündemindeki konular bakımından üyelik haklarının ne şekilde ve kimin tarafından yerine getirileceği konusunda, Topluluk ile üye devletler tarafından ortak tutum (common position) belirlenerek hareket edilmesi gerekmektedir ${ }^{40}$.

AT'nin milletlerarası özel hukuk alanındaki yetkisinin kaynağını teşkil eden ve Kurucu Antlaşmanın IV. Başlığı altında yer alan 61. maddesinin (c) bendi ile 65 . maddesi ise, Topluluğa bu alanda düzenleme yapma yetkisi tanımakla yetinmiş, dış yetkiye dair herhangi bir hükme yer vermemiştir ${ }^{41}$.

Divan'ın 1/94 sayılı Görüşü uyarınca bazı durumlarda söz konusu yetkinin münhasır nitelikte bulunmasına karşın, Topluluk, üyeliği sadece devletler bakımından mümkün olan Uluslararası Çalışma Örgütü (International Labour Organisation (ILO))'nde üye değil, gözlemci statüsündedir. Açılama için bkz. GOVAERE/ CAPIAU/ VERMEERSCH, s. 164.

${ }^{39}$ FRID, s. 353 vd.; MACLEOD/ HENDRY/ HYETT, s. 171.

${ }^{40}$ MACLEOD/ HENDRY/ HYETT, s. 171. Uygulamada, Topluluk ile üye ülkelerin birlikte üye oldukları bir uluslararası örgüt içerisinde tartışılan hususlar bakımından ne şekilde tavır alınacağı, kimin konuşma hakkını ve oy hakkını kullanacağı gibi hususlar, önceden Topluluk ile üye devletlerin katılımı ile gerçekleşen koordinasyon toplantılarında belirlenmektedir. Ancak bu konuda, Topluluk ile üye devletlerin aralarında geçerli olacak kuralları önceden belirlemeleri de mümkündür. Bu șekilde bir düzenleme, AT’nin, 1991 yılında gerçekleşen FAO üyeliği sonrasında Avrupa Komisyonu ve AB Konseyi arasında kabul edilmiştir. Söz konusu düzenleme, FAO toplantıları öncesinde ilgili dokümanların dağıtımı, söz konusu toplantılarda Topluluk ile üye ülkeler arasındaki yetki paylaşımı ile kimin konuşma ve oy hakkı olduğu gibi konularda geçerli olan esaslara yer vermiştir: Bkz. EECHOUT, s. 212 vd; MACLEOD/ HENDRY/ HYETT, s. 177- 178.

41 Antlaşmanın 61. maddesinin (c) bendinde, "Özgürlük, güvenlik ve adalet alanının yaratılabilmesi için Konsey, 65. maddede yer aldı̆̆ı şekilde özel hukuk alanında adlî işbirliğine ilişkin önlemleri alır" hükmü getirilmiş; 65. maddede ise, alınacak önlemlerin kapsam ve şartları düzenlenmiştir. Buna göre, özel hukuk alanında adlî işbirliğine ilişkin ve sınır aşıcı etkilere sahip önlemler, 67. madde uyarınca ve iç pazarın düzgün işleyişisinde gerekli olduğu ölçüde: (a) -mahkeme ya da mahkeme dişı organlarca verilen belgelerin sınır ötesi tebliğine ilişkin sistemin, -delillerin alınmasına ilişkin işbirliğinin, - mahkeme dışı davalarda verilen kararlar da dahil olmak üzere, medenî hukuk ve ticaret hukuku davalarına ilişkin kararların tanınması ve tenfizinin geliştirilmesi ve sadeleştirilmesi; (b) üye devletlerde uygulanan kanunlar ihtilâfı ve mahkemelerin yargı yetkisine ilişkin kuralların uyumunun geliştirilmesi; (c) medenî yargılamanın iyi işleyişi önündeki engellerin, gerektiğinde üye devletlerde uygulanan medenî usûl kurallarının uyumunun geliştirilmesi suretiyle, kaldırılmasını kapsamaktadır. Söz konusu hükümler hakkında bkz. BAYRAKTAROĞLU ÖZÇELIK, s. ** vd.; BOELE-WOELKI, K./ VAN OOIK, R. H.: "The Communitarization of Private International Law", YPIL, Y. 2002, Vol. 4, s. 1-36; BASEDOW, J.: "The Communitarization of the Conflict of Laws Under the Treaty of Amsterdam", CMLR, Y. 2000, Vol. 37, s. 687-708; BAYRAKTAROĞLU, s. 127 vd.; EKŞİ, N.: Sözleşmeden Doğan Borçlara Uygulanacak Hukuk Hakkında Roma Konvansiyonu, İstanbul 2004, s. 10 vd.; BETLEM, G./ HONDIUS, E.: "European Private 
Dolayısıyla, Topluluğun milletlerarası özel hukuk alanı bakımından Kurucu Antlaşma hükümleri uyarınca açıkça tanınmış bir dış yetkisi yoktur. Ancak, Topluluğun bu alanda zımnî dış yetkiye sahip olduğu hem doktrinde hem de ATAD'ın yeni Lugano Konvansiyonunun akdine ilişkin olarak açıkladığı görüşünde kabul edilmiştir ${ }^{42}$.

$\mathrm{Bu}$ anlamda doktrinde, özellikle ERTA kararına dayanılarak milletlerarası özel hukuk alanında Topluluğun dış yetkisinin, bu alanda Topluluğa iç yetki veren Antlaşmanın IV. Başlığından zımnen doğmuş olduğu fikri kabul görmüştür ${ }^{43}$. Divan da, Lugano Görüşünde ${ }^{44}$, ERTA kararına atıf yapmak suretiyle, Topluluğun mahkemelerin yetkisi, tanıma ve tenfiz konuları bakımından dış yetkisinin zımnen var olduğunu, bu alanda mevcut Topluluk tasarruflarının varlığı sebebiyle kabul etmiştir. Bu anlamda Divan, Kurucu Antlaşmanın 61 ve 67. maddeleri uyarınca çıkarılmış olan Hukukî ve Ticarî Konularda Yarg1 Yetkisi, Yargı Kararlarının Tanınması ve Tenfizine Dair Konsey Tüzüğü (Brüksel I Tüzüğ̈̈̈) ${ }^{45}$ ile 40/94 sayılı ve 20 Aralık 1993 tarihli Topluluk Markasına Dair Konsey Tüzüğü ${ }^{46}$ ya da Hizmet Sunumu Çerçevesinde İşçilerin Gönderilmesine İlişkin 96/71 sayılı ve 16 Aralık 1996 tarihli Direktif ${ }^{47}$ gibi muhtelif konularda çıkarılmakla birlikte mahkemelerin yetkisi, tanıma ve tenfiz konularında da hüküm getiren Topluluk düzenlemelerinin zımnî dış yetkiye sebep olduğunu ifade etmiştir ${ }^{48}$.

Law after the Treaty of Amsterdam”, ERPL, Y. 2001, Vol. 1, s. 10 vd.; ÇIÇEKLİ, B.:"Avrupa Birliğinde Özel Hukukta Adlî İşbirliği ve Mahkeme Kararlarının Serbest Dolaşımı", <http://www.turkaydanismanlik.com/tr/docs/Avrupa_birliginde_ozel_hukukta_a dli_isbirligi_ve_kararlarin_serbest_dolasimi.pdf> (13.01.2008); REMIEN, O.: "European Private International Law, The European Community and Its Emerging Area of Freedom, Security and Justice", CMLR, Y. 2001, Vol. 38, s. 53-86; BOGDAN, M.: Concise Introduction to EU Private International Law, Groningen 2006, s. 3 vd.

42 Topluluğun milletlerarası özel hukuk alanındaki dış yetkisi hakkında bkz. BAYRAKTAROĞLU ÖZÇELIK, s. $22 \mathrm{vd}$.

${ }^{43}$ BOELE-WOELKI/ VAN OOIK, s. 19 ve BOELE-WOELKI/ VAN OOIK, s. 19, dn. 60'da anılan yazarlar; BASEDOW, s. 704; REMIEN, s. 75; KRUGER, T.: "Opinion 1/03, Competence of the Community to Conclude the New Lugano Convention on the Jurisdiction and the Recognition and Enforcement of Judgements in Civil and Commercial Matters", CJEL, Y. 2006-2007, Vol. 13, s. 192.

${ }_{45}^{44}$ Bkz. yuk. dn. 4.

45 Council Regulation (EC) No 44/2001 of 22 December 2000 on jurisdiction and the recognition and enforcement of judgments in civil and commercial matters, OJ $2001 \mathrm{~L}$ $12 / 1$.

${ }^{46}$ Council Regulation (EC) No 40/94 of 20 December 1993 on the Community Trade Mark, O.J. 1994 L 11/1.

${ }^{47}$ Directive 96/71/EC of the European Parliament and of the Council of 16 December 1996 concerning the posting of workers in the framework of the provision of services, O.J. 1997 L 018/1.

${ }^{48}$ Lugano Görüşü, para. 134. 
Topluluğun La Haye Konferansına üyeliğinde de Antlaşmanın IV. Başlığı altındaki 61. maddenin (c) fikrasına dayanılmıştır ${ }^{49}$.

Buna karşın, Topluluğun milletlerarası özel hukuk alanında sahip olduğu dış yetkinin münhasır nitelikte bulunup bulunmadığı konusunda genel bir tespit yapmak kolay değildir. Ancak bu sorunun çözümü, Topluluğa üye ülkelerin yanı sıra, La Haye Konferansına üye olan AT'nin, La Haye Sözleşmelerine taraf olmak bakımından münhasıran yetkili olup olmadığ konusunda, azami öneme sahiptir ${ }^{50}$. Bu konuda da, Divan'in Lugano Görüşüne benimsediği yaklaşım çerçevesinde bir takım sonuçlara ulaşılabilir. ATAD, Lugano Görüşünde, ERTA kararında münhasır nitelikteki dış yetkiye ilişkin açıkladığı görüşüne paralel olarak ${ }^{51}$, Topluluk hukuku kurallarının yeknesak ve tutarlı uygulanmasını ve bu kuralların kurduğu sistemin etkili işleyişini etkileyebilecek nitelikteki bir uluslararası anlaşmanın akdi konusunda, Topluluğun münhasıran yetkili olduğunu belirttikten sonra; Topluluk hukukunun yarg1 yetkisine ve yarg1 kararlarının tanınması ve tenfizine dair kurallarının ve bu anlamda, en önemli Topluluk düzenlemesi olarak Brüksel I Tüzügünün, yeknesak ve tutarlı bir sistem oluşturduğunu, tarafları arasında benzer bir sistem yaratmayı amaçlayan yeni Lugano Konvansiyonunun ise Topluluk hukuku kurallarının uyumlu ve tutarlı olarak uygulanmasını ve bu kuralların kurduğu sistemin düzgün işleyişini etkileyeceğini ifade etmiştir ${ }^{52}$. Ancak bununla birlikte, Divan'ın söz konusu görüşünde önemle belirttiği bir husus, Topluluğun sinırlı yetki prensibine dayandığından hareketle, özellikle münhasır dış yetkinin Kurucu Antlaşmada açıkça düzenlenmediği alanlar bakımından, yapılması düşünülen uluslararası anlaşmanın Topluluk hukukunu etkileyip etkilemediğinin özel olarak incelenmesi gerektiği ve ancak böyle bir inceleme sonucu uluslararası anlaşmanın Topluluk hukuku kurallarını etkileyeceğinin şüpheye yer olmayacak şekilde tespit edilmesi durumunda, Topluluğun münhasır yetkisinin söz konusu olacağıdır ${ }^{53}$. Söz konusu incelemede, her iki düzenlemenin kapsamlarının yanı sıra, bunlarda yer alan hükümlerin içerik ve niteliklerinin ve hatta Toplulukta bu alanda öngörülebilen gelişmelerin de dikkate alınması gerekmektedir ${ }^{54}$.

Lugano Görüşünden genel olarak Topluluğun milletlerarası özel hukuk alanındaki dış yetkisinin kullanımının ne şekilde etkileneceği şu an itibariyle belirsizliğini korumaktadır. Söz konusu belirsizlik özellikle, Divan'ın yeni Lugano Konvansiyonunun imzalanması konusunda AT'nin münhasıran

\footnotetext{
${ }^{49}$ Bkz. yuk. dn. 33.

50 AT’nin La Haye Konferansına üyeliğinin La Haye Sözleşmeleri bakımından sonuçları konusunda bkz. aşa. Başlık (IV).

${ }^{51}$ ERTA Kararı, para. 17.

${ }^{52}$ Lugano Görüşü, para. 160, 161, 172.

${ }^{53}$ Lugano Görüşü, para. 124.

${ }^{54}$ Lugano Görüşü, para. 126, 133.
} 
yetkili olduğunu kabul etmiş olmasının, Topluluğun milletlerarası özel hukuk alanının bütünü bakımından da münhasır yetkili sayılmasına imkân verdiği şeklinde yorumlanıp yorumlanmayacağına ilişkindir. Doktrinde, bu soruya olumlu yanıt verenler olduğu gibi, Lugano Görüşünün Lugano Sözleşmesi ile sınırlı olarak değerlendirilmesi gerektiği ve kolayca milletlerarası özel hukuk alanının bütünü bakımından bir sonuca varılamayacağını savunan yazarlar da mevcuttur ${ }^{55}$.

Kanaatimizce, bu Görüşte Divanın defalarca Topluluk hukuku kurallarının uygulanmasını etkileyip etkilemeyeceğinin, yapılacak milletlerarası anlaşma ile Topluluk kurallarının kapsamlarının ve hükümlerinin içerik ve niteliklerinin ve hatta Toplulukta bu alanda yapılması düşünülen düzenlemelerin de öngörülebildiği ölçüde dikkate alınacağı bir incelemeye tâbi tutulması gerektiğini belirtmiş olması, bu Görüşün yeni Lugano Konvansiyonu ile sınırlı olduğu fikrini kuvvetlendirmektedir. Gerçekten, eğer milletlerarası özel hukuk alanına dahil bir konuda Topluluğun münhasıran yetkili olup olmadığının tespiti, bir yanda yapılması düşünülen uluslararası anlaşma, diğer yanda ilgili Topluluk hukuku kurallarının ayrıntılı incelemesi sonucu Topluluk hukuku kurallarının etkilenip etkilenmediğinin tayini ile yapılacaksa, o halde, a priori olarak herhangi bir sonuca varmak mümkün olmamal1, her somut sözleşme bakımından, ilgili Topluluk düzenlemeleri dikkate alınarak bir sonuca ulaşılmalıdır. Bununla birlikte, Görüşte ifade edilen, sadece mevcut Topluluk düzenlemelerinin değil, sözleşmenin konusuna ilişkin alanda Topluluktaki gelişmelerin dahi, Topluluğun münhasır yetkisinin tayininde temel teşkil edeceği yaklaşımından hareket edilirse, söz konusu alanda Topluluk kurumları tarafından hazırlanan bir çok belgenin (Komisyon tasarılarının, hareket plânları ve yeşil kâğıtlar gibi), Topluluğun münhasıran yetkili kabul edilmesine gerekçe olarak gösterilmesi mümkündür.

III- Avrupa Topluluğunun La Haye Konferansına Üyeliğinin Kurumsal Çerçevesi

\section{A) Avrupa Topluluğu ile La Haye Konferansı Arasındaki İlişkilerin} Gelişimi

AT’nin La Haye Konferansına üyeliği ile önemli bir noktaya gelen iki örgüt arasındaki ilişkiler, söz konusu üyelik öncesinde bir yandan AT'nin, kurulduğu 1957 yllından itibaren Konferans içerisinde sahip olduğu gözlemci statüsü, diğer yandan Konferansa üye olan AT üyesi ülkeler aracıllğıyla ilerlemiştir. AT üyesi devletlerin hepsi, bugün üye sayısı altmış dokuzu bulan Konferansa üye bulunmakla, Konferans içerisinde önemli bir çoğunluğu ifade etmiştir. Söz konusu devletlerin tümü, Konferansın statüsü

\footnotetext{
${ }^{55}$ Konuya ilişkin farklı görüşler ve ayrıntılı tartışmalar için bkz. POCAR, s. 7 vd.
} 
dışında, 5 Ekim 1961 tarihli Apostille Konvansiyonu ${ }^{56}$ ile 25 Ekim 1980 tarihli Çocuk Kaçırmaya İlişkin Konvansiyona ${ }^{57}$ taraf olmuşlardır ${ }^{58}$. Gözlemci statüsü ise Topluluğa, Konferans toplantılarında tartışmalara katılma ve öneri sunma imkânı vermişse de, Topluluk resmen Konferans üyeliğine sahip olmadığından, oy hakkı tanımamıştır ${ }^{59}$. Diğer yandan, Topluluk, mevcut La Haye Sözleşmelerine de, söz konusu sözleşmelerin sadece devletlerin katılımına açık olması sebebiyle, katılamamıştır.

Amsterdam Antlaşmasının yürürlüğe girmesiyle birlikte ise, Toplulukta milletlerarası özel hukuka dair yaşanan gelişmeler, Konferans gündemini işgal etmeye başlamıştır. Bu dönemde, milletlerarası özel hukukun bölgesel düzeyde yeknesaklaştırılmasının Konferans çalışmaları üzerinde önemli ölçüde etkili olacağı üzerinde durulmuş ve bir yandan Konferansin çekirdeğini oluşturan AT üyesi ülkeler arasında Topluluk düzenlemelerinin uygulanması sebebiyle La Haye Sözleşmelerinin öneminin azalacağı, diğer yandan ise, söz konusu ülkelerin ortak tutum belirlemek durumunda olmaları halinde sözleşme müzakerelerinin olumsuz etkilenebileceği endişesi hâkim olmuştur $^{60}$. $\mathrm{O}$ dönemde, bölgesel entegrasyonun, La Haye Konferansı üzerindeki olası olumsuz etkilerinin azaltılabilmesi amacıyla, La Haye Sözleşmelerine Topluluğun katılımını sağlayan hükümlere yer verilmesi ve Topluluğun La Haye Konferansina üyeliği geleceğe dair planlar arasında ifade edilmiştir ${ }^{61}$.

Bu konuda ilk adım, müzakeresi kısmen ya da tamamen Amsterdam Antlaşmasının yürürlüğe girdiği döneme rastlayan La Haye Sözleşmelerinin müzakerelerinde Topluluğun aktif bir şekilde yer alması sebebiyle, söz konusu sözleşmelere "bölgesel ekonomik entegrasyon örgütleri"nin de katılımı konusunda hüküm konmakla atılmıștır. Bu anlamda 2006 tarihli Menkul Kıymetler Sözleşmesi ${ }^{62}$ (m. 18) ve 2005 tarihli Yetkili Mahkeme

${ }^{56}$ Convention of 5 October 1961 Abolishing the Requirement of Legalisation for Foreign Public Documents. Sözleşme metni için bkz. <http://www.hcch.net/index_en.php?act= conventions.text\&cid=41> (01.04.2008).

57 Convention of 25 October 1980 on the Civil Aspects of International Child Abduction. Sözleşme metni için bkz. <http://www.hcch.net/index_en.php?act=conventions.text\&cid $=24>(01.04 .2008)$.

${ }^{58}$ HAGUE CONFERENCE ON PRIVATE INTERNATIONAL LAW: "Examination by the European Community of Existing Hague Conventions- Note Drawn up by the Secretary General of the Hague Conference of Private International Law", <www.hcch.net> (15.02.2008).

${ }^{59}$ SCHULZ, s. 942

${ }^{60}$ VAN LOON, s. 233.

${ }^{61}$ VAN LOON, s. 233- 234; SCHULZ, s. 940.

${ }^{62}$ Convention of 5 July 2006 on the Law Applicable to Certain Rights in respect of Securities held with an Intermediary. Sözleşme metni için bkz. <http://www.hcch.net/index_en.php? act=conventions.text\&cid=72 > (01.04.2008). Sözleşmenin açıklayıcı raporu için bkz. GOODE, R./ KANDA, H./ KREUZER, K.: "Explanatory Report on the 2006 Hague 
Seçimine Dair Sözleşmede ${ }^{63}$ (m. 29), Konferansın yeni Statüsünde bölgesel ekonomik entegrasyon örgütlerine dair yer alan 3. maddedeki düzenlemenin bir benzeri yer almıştır. Söz konusu Sözleşmeler henüz AT ve/veya üye devletler tarafından imzalanmamıştır ${ }^{64}$.

Konu, Mayıs 2000'de AT'nin de temsil edildiği La Haye Konferansı Genel İşler ve Politika Komisyonu toplantısında da tartışılmıştır. Toplantıda, milletlerarası özel hukuk alanında Toplulukta yaşanan gelişmelere dikkat çekilmiş, özellikle Topluluğun milletlerarası özel hukuka dair düzenleme yapma yetkisine sahip olmasının, La Haye Konferansının uluslararası alanda sahip olduğu role zarar vermemesi ve iki örgüt arasındaki işbirliğinin geliştirilerek, Topluluğun mevcut La Haye Sözleşmelerine katılımı ve Konferansa üyeliği konusunda bir yöntemin kabul edilmesi gerekliliği ifade edilmiştir $^{65}$.

Bu toplantının akabinde, konu Konferans gündemine taşınmıştır. Nisan 2002'de gerçekleşen Konferansın 19. Birleşiminde, Konferans sekretaryası tarafından bölgesel örgütlerin La Haye Sözleşmelerine taraf olma imkânı ile La Haye Konferansina üyelikleri konusunda hazırlanan bilgi notu çerçevesinde tartışılmış, FAO ve DTÖ Statüleri örnek gösterilmek suretiyle, Konferans statüsünde yapılacak bir değişiklikle bölgesel örgütlerin üyeliğinin de mümkün olabileceğine dikkat çekilmiştir ${ }^{66}$. Avrupa Komisyonu AB Konseyi tarafından 28 Kasım 2002'de La Haye Konferansına üyelik şart ve biçimlerinin müzakere edilmesi amacıyla yetkilendirildikten sonra ise, 19 Aralık 2002 tarihinde Topluluk, üyelik başvurusunu yaparak müzakerelerin başlamasını talep etmiş̧tir.

Topluluğun üyelik başvurusunun akabinde, Topluluk kurumlarınca özel hukukta adlî işbirliği konusunda hazırlanan tüm belgelerde de La Haye Konferansı üyeliği ile La Haye Sözleşmelerine katılımın değerlendirilmesi yakın tarihli planlar arasında yer almıştır. Bu anlamda, Avrupa Konseyi (Zirve) tarafından 4 Kasım 2004'te kabul edilen ve 2005-2010 dönemi için

Securities Convention", <http://www.hcch.net/index_en.php?act=publications.details\&pid $=2955>(01.04 .2008)$.

${ }^{63}$ Convention of 30 June 2005 on Choice of Court Agreements. Sözleşme metni için bkz. <http://www.hcch.net/index_en.php?act=conventions.text\&cid=98> (01.04.2008). Sözleşmenin açıklayıcı raporu için bkz. HARTLEY, T./ DOGAUCHI, M.: "Explanatory Report on the 2005 Hague Choice of Court Agreements Convention", <http://www.hcch.net/upload/expl37e.pdf> (01.04.2008).

${ }^{64}$ Söz konusu Sözleşmeler hakkında bkz. aşa. Başlık (IV).

65 TRAEST, M.: "Development of a European Private International Law and the Hague Conference", YPIL, Y. 2003, Vol. 5, s. 240.

66 Söz konusu bilgi notu için bkz. HAGUE CONFERENCE ON PRIVATE INTERNATIONAL LAW, "Note on the Impact of Regional Integration, in Particular within the European Union, on the Hague Conference and the Hague Conventions", Preliminary Document No. 14 of June 2001, <http://www.hcch.net/upload/wop/genaff2001 _pd14e.pdf> (02.04.2008) (Preliminary Document No. 14 of June 2001). 
özgürlük, güvenlik ve adalet alanı bakımından hedefleri kapsayan La Haye Programı ${ }^{67}$, Avrupa Komisyonu tarafından 2005 yılında hazırlanan özgürlük, güvenlik ve adalet alanının uluslararası boyutuna ilişkin strateji belgesi ${ }^{68}$ ile La Haye Programının uygulanmasına ilişkin takvim öngören hareket plânı ${ }^{69}$ ve Nisan 2006' da AB Konseyi tarafından hazırlanan özgürlük, güvenlik ve adalet alanının uluslararası boyutuna ilişkin belge ${ }^{70}$ sayılabilir.

La Haye Konferansı çatısı altında ise, Topluluğun üyeliği meselesi, üyelik başvurusunun akabinde, Topluluğun Konferansa üyelik başvurusunu bütün yönleri ile değerlendirmek amacıyla kurulan gayri resmî danışma grubu toplantılarında ve 1-3 Nisan 2003, 6-8 Nisan 2004 ve 31 Mart- 1 Nisan 2005 tarihli Genel İşler ve Politika Komisyonu toplantılarında tartışılmıștır. Söz konusu toplantıların temel gündem maddelerini, Konferans statüsünde yapılması gerekli değişiklikler ile AT'nin La Haye Sözleşmelerine katılım yönteminin ne olması gerektiği teşkil etmiştir. Bununla birlikte, Topluluğun üyeliğinin gerçekleşebilmesi için statü değişikliğinin sağlanması gerekliliği sebebiyle üyeliğin resmen gerçekleşmesi, statü değişikliğin yapılması sonrasına kalmıştır ${ }^{71}$. Bu itibarla, Genel İșler ve Politika Komisyonu tarafından Statüye dair değișiklik önerileri (usûl kurallarına dair değişiklikler ile birlikte) ${ }^{72} 30$ Haziran 2005'te gerçekleşen yirminci diplomatik konferansa sunulmuş ${ }^{73}$ ve AT’nin üyelik

67 The Hague Programme: strengthening freedom, security and justice in the European Union, <http://ec.europa.eu/justice_home/doc_centre/doc/hague_programme_en.pdf> (01.04.2008).

${ }^{68}$ Commission Communication: A strategy on the external dimension of the area of freedom, security and justice, COM(2005) 491 final.

${ }^{69}$ Communication from the Commission to the Council and the European Parliament - The Hague Programme: Ten priorities for the next five years The Partnership for European renewal in the field of Freedom, Security and Justice, COM/2005/0184 final.

${ }^{70}$ Note from the Council of the European Union, 11 April 2006, 8140/06 LIMITE JUSTCIV 93, s. 6.

71 Topluluğun üyeliğinin gerçekleşebilmesi için La Haye Konferansı Statüsünde yapılması gerekli değişiklikler konusunda gerek resmî Genel İşler ve Politika Komisyon toplantılarında gerekse gayrî resmi toplantılarda yapılan tartışmalar ve Statü değişikliğine dair öneriler için bkz. HAGUE CONFERENCE ON PRIVATE INTERNATIONAL LAW: "Note on the Admission of the European Community to the Hague Conference on Private International Law", Update to Preliminary Document No. 13 of February 2004, <http://www.hcch.net/upload/wop/genaff_pd20e.pdf> (02.04.2008) (Update to Preliminary Document No. 13 of February 2004).

72 Diplomatik Konferans ve Komisyon toplantılarında geçerli olan usûl kuralları için bkz. <http://hcch.e-vision.nl/upload/rules_e.pdf> (02.04.2008).

73 HAGUE CONFERENCE ON PRIVATE INTERNATIONAL LAW: Draft Recommendation to the Twentieth Session of the Hague Conference on Private International Law on the admission of the European Community, Preliminary Document No. 21A of February 2005, <http://www.hcch.net/upload/wop/genaff_pd21ae.pdf > (02.04.2008); HAGUE CONFERENCE ON PRIVATE INTERNATIONAL LAW: Draft Recommendation to the Twentieth Session of the Hague Conference on Private International Law on the admission of the European Community, Preliminary Document 
başvurusunun akabinde başlayan iki buçuk senelik çalışma neticesinde aynı tarihte kabul edilmiştir ${ }^{74}$. Yeni Konferans Statüsü 1 Ocak 2007 tarihinde yürürlüğe girmiştir ${ }^{75^{3}}$. Topluluğun üyeliği ise, 3 Nisan 2007 'de, Konferans Statüsünü kabul ettiğine dair belgeyi tebliği ile gerçekleşmiştir.

\section{B) La Haye Konferansı Üyesi Olarak Avrupa Topluluğunun Hak ve Yüküimlülükleri}

AT'nin La Haye Konferansına üyeliği ile birlikte sahip olduğu hak ve yükümlülükler, esas itibariyle yeni Konferans Statüsünün 3. maddesinde düzenlenmiştir. Her ne kadar Statü değişikliklerine dair Genel İşler ve Politika Özel Komisyonu toplantılarında, Topluluğun La Haye üyeliğinden kaynaklanan hak ve yükümlülüklerinin, Statüde yer almayıp, AT ile La Haye Konferansı arasında yapılacak ayrı bir anlaşmada düzenlenmesi tartışılmışsa da, bu öneri, nihaî olarak kabul görmemiş ve söz konusu hükümlere yeni Statiu içerisinde yer verilmiştir ${ }^{76}$.

Ancak söz konusu düzenlemelere geçmeden önce, Konferansın tarihi bakımından önemli bir değişiklik getiren, Konferansa devletlerin yanı sıra "bölgesel ekonomik entegrasyon örgütleri"nin de üye olmasına ilişkin yeni düzenlemenin de açıklanması faydalı olacaktır. Öncelikle belirtmek gerekir ki, Topluluğun La Haye Konferansına katılımını sağlayan hükümler, özel olarak AT bakımından değil, fakat ileride farklı örgütlerin de Konferansa katılımına imkân tanınabilmesi amacıyla genel nitelikte düzenlenmiştir. Bu anlamda, Topluluğun FAO üyeliğinin gündeme gelmesiyle 1991 tarihinde değişikliği uğrayan FAO Statüsünün 2. maddesinin 4. fikrasında yer alan düzenleme esas alınmıştır.

Statünün 3. maddesinin 1. fikrasında getirilen düzenleme ile "Konferansa üye ülkelerin çoğunluğunun mevcut olduğu genel işler ve politikaya ilişkin bir toplantıda, üyelik için başvurmuş bir bölgesel ekonomik entegrasyon örgütünün üyeliğine oyların çoğunluğu ile karar verebileceği"’

No. 21B of February 2005, <http://www.hcch.net/upload/wop/genaff_pd21be.pdf> (02.04.2008) (Preliminary Document No. 21B of February 2005).

74 HAGUE CONFERENCE ON PRIVATE INTERNATIONAL LAW: Twentieth SessionFinal Act, 30th June 2005, <http://www.hcch.net/upload/finalact20e.pdf>, (11.04.2008), s. $25 \mathrm{vd}$.

75 Konferansın yeni Statüsü için bkz. <http://www.hcch.net/index_en.php?act $=$ conventions.pdf\&cid=29> (11.04.2008). Konferans Statüsündeki değişiklikler, esas itibariyle bölgesel ekonomik entegrasyon örgütlerinin üyeliğine ilişkin olmakla birlikte, Statünün 50 yıllık geçmişi de dikkate alınarak küçük çapta olmak üzere başka bazı değişiklikler de yapılmıştır. Bununla birlikte, Statüde köklü bir değişikliğe gidilmesi, söz konusu değişiklik sürecinin uzun süreceği ve Topluluğun üyeliğini geciktireceği düşüncesiyle kabul görmemiştir. Bkz. HAGUE CONFERENCE ON PRIVATE INTERNATIONAL LAW, Preliminary Document No. 21B of February 2005, s. 3.

${ }^{76}$ HAGUE CONFERENCE ON PRIVATE INTERNATIONAL LAW, Update to Preliminary Document No. 13 of February 2004, s. 4; EK I, s. 7 vd. 
hükme bağlanmıştır. Aynı maddesinin 2. fıkrasında ise, Konferansa üye olmak isteyen bölgesel ekonomik entegrasyon örgütünün taşıması gereken şartlar belirtilmiştir. Buna göre, söz konusu örgüt üyelerinin yalnızca egemen devletlerden oluşması ve söz konusu devletler tarafından örgüte belli konularda, bağlayıcı karar alma yetkisi de dahil olmak üzere, yetki devredilmiş bulunması gerekmektedir ${ }^{77}$. Nitekim, bölgesel ekonomik entegrasyon örgütü, Statünün 3. maddesinin 9. fikrasında, "üyelerini yalnızca egemen devletlerin oluşturduğu ve söz konusu devletler tarafından kendisine belli konularda bağlayıcı karar alma yetkisi de dahil olmak üzere yetki devredilmiş bulunan uluslararası örgüt" şeklinde tarif edilmiştir.

Statü değişikliklerinin tartışıldığı danışma grubu toplantılarında ve hatta söz konusu değişikliklerin kabul edildiği Konferansın yirminci birleşiminde "bölgesel ekonomik entegrasyon örgütü" kavramına ilişkin tartışmalar "bölgesel" ve "ekonomik" kavramlarında yoğunlaşmış ve bölgesel ve ekonomik sınırlandırmaların yer almadığı "uluslararası örgüt" kavramının kabul edilmesi önerilmişti ${ }^{78}$. Bu öneri, bölgesel sınırları aşan ve ekonomik entegrasyonun ötesinde amaçları bulunan örgütlerin de üyeliğine imkân sağlanması fikrine dayandırılmış ve Konferansa üyeliği tartışılan AT'nin dahi, gelinen noktada sadece ekonomik entegrasyonu amaçlamadığı savunulmuştur ${ }^{79}$. Ancak, toplantıda "bölgesel ekonomik entegrasyon örgütü" kavramı çeşitli gerekçelerle kabul edilmiştir: Öncelikle bu kavram, çeşitli uluslararası metinlerde sıklıkla kullanılmış ve benimsenmiş bir kavram olması sebebiyle tercih edilmiş, aynı kavramın, FAO Statüsünün yanı sıra, 1999 yılından sonra hazırlanan La Haye Sözleşmeleri ve UNIDROIT öncülüğ̈̈̈nde hazırlanan 2001 tarihli Cape Town Konvansiyonu ${ }^{80}$ gibi uluslararası metinlerde de yer aldığı ifade edilmiştir. Bunun yanı sıra, üyelik için başvuran örgütte aranan "bölgesel" ve "ekonomik" örgüt olma şartlarının, asgari şartları oluşturduğu; dolayısıyla bölgesel sınırların ve

\footnotetext{
${ }^{77} \mathrm{Bu}$ şartlara ek olarak, üyelik için başvuran bölgesel ekonomik entegrasyon örgütüne üye ülkelerin de Konferansa üye olması şartı aranmamıştır. Dolayısıyla, bölgesel ekonomik entegrasyon örgütünün üyelerinden hiçbiri La Haye Konferansına üye olmasa dahi, diğer şartların gerçekleşmesi durumunda örgütün Konferansa üyeliğinin gerçekleşmesi mümkündür. $\mathrm{Bu}$ anlamda bölgesel ekonomik entegrasyon örgütünün üyeliği için, söz konusu örgüte üye olan devletlerin çoğunluğunun öncelikle üye olması gerektiği bir şart olarak kabul eden FAO statüsü ile La Haye Statüsü arasında bir fark oluşmuştur: Bkz. SCHULZ, s. 945.

${ }^{78}$ HAGUE CONFERENCE ON PRIVATE INTERNATIONAL LAW, Update to Preliminary Document No. 13 of February 2004, EK I, s. 7. Konferansin söz konusu toplantısında yapılan tartışılan konular için bkz. KRUGER, T.: "Current Developments- Private International Law: The 20th Session of the Hague Conference: A New Choice of Court Convention and the Issue of EC Membership", ICLQ, Y. 2006, Vol. 55, s. 455.

${ }^{79}$ SCHULZ, s. 944.

${ }^{80}$ Convention on International Interests in Mobile Equipment. Sözleşme metni için bkz. <http://www.unidroit.org/english/conventions/mobile-equipment/mobile-equipment.pdf> (29.02.2008).
} 
ekonomik entegrasyon amacının ötesine geçen örgütlerin de üyeliklerinin gündeme gelebileceği de vurgulanmıştır ${ }^{81}$. Ayrıca, bölgesel ekonomik entegrasyon örgütü ile vurgulanmak istenen "üyeleri bakımından doğrudan bağlayıcı kararlar alabilme" özelliğinin de, daha genel kapsamlı uluslararası örgüt kavramı ile en azından her zaman karşılanamayacağı belirtilmiştir ${ }^{82}$. Ancak söz konusu tartışmalar neticesinde, bölgesel ekonomik entegrasyon örgütü kavramı tanımlanırken, uluslararası örgüt kavramına da yer verilmiştir.

\section{1- Avrupa Topluluğu ile Topluluğa Üye Ülkeler Arasındaki Yetki Paylaşımı ve Avrupa Topluluğunun Yetki Bildirisi}

Genel olarak AT'nin uluslararası örgütlere üyeliğinde problemli görülen hususlardan en önemlisi, Topluluk ile üye devletler arasındaki yetki paylaşımına ilişkindir. Buna karşın bu sorunun çözümü, özellikle Topluluk ile Topluluğa üye devletlerin birlikte bir uluslararası örgüte üye olmaları durumunda, gündemi oluşturan konu bakımından Topluluk ve üye devletlerden hangisinin konuşma ve oy hakkına sahip olacağının tayini bakımından önem taşır ${ }^{83}$. Uygulamada bu problem, Topluluktan istenen yetki bildirisi (declaration of competence) ile aşılmaya çalışılmaktadır ${ }^{84}$.

La Haye Konferansı statüsünde yapılacak değişikliğin tartışıldığı komisyon toplantılarında da, milletlerarası özel hukuk alanında yetkinin AT ile üye devletler arasında ne şekilde paylaşıldığı ve yetki paylaşımının gelecekteki La Haye Sözleşmelerine etkisine ilişkin tartışmalar sıklıkla gündeme gelmiştir ${ }^{85}$. Bu konuya ilişkin olarak, AT üyesi olmayan La Haye Konferansı üyesi devletler, her ne kadar Topluluk ile üye devletler arasındaki yetki paylaşımının tartışmalı yanları olan ve sürekli değişim içinde bulunan bir konu olduğunu kabul ettiklerini ifade etmişlerse de, bu konunun La Haye Konferansı kapsamında bir şekilde çözüme kavuşturulmasını, bir yandan, La Haye Sözleşmelerinin müzakere ve imzasının kimin tarafından yürütüleceğinin, diğer yandan ise, imzalanan Sözleşmelerin uygulanmasından kimin sorumlu olacağının tayini bakımından önemli olduğunu vurgulamışlardır ${ }^{86}$.

Yeni Konferans Statüsünde, bölgesel ekonomik entegrasyon örgütü ile üyeleri arasındaki yetki paylaşımına ilişkin hususlar, büyük ölçüde FAO

\footnotetext{
${ }^{81}$ SCHULZ, s. 944.

${ }^{82}$ SCHULZ, s. 944.

${ }^{83}$ FRID, s. 335 vd.

${ }^{84}$ AT'nin uluslararası örgütlere üyeliğinde sunulan yetki bildirileri, kapsam ve nitelikleri konusunda bkz. FRID, s. 354; MACLEOD/ HENDRY/ HYETT, s. 174, 161.

${ }^{85}$ HAGUE CONFERENCE ON PRIVATE INTERNATIONAL LAW, Update to Preliminary Document No. 13 of February 2004, EK I, s. 4.

${ }^{86}$ HAGUE CONFERENCE ON PRIVATE INTERNATIONAL LAW, Update to Preliminary Document No. 13 of February 2004, EK I, s. 4.
} 
Statüsündeki düzenleme ${ }^{87}$ esas alınarak, 3. maddenin 3 ilâ 6. fikralarında düzenlenmiştir. Söz konusu hükümlerde Konferansa üyelik başvurusunda bulunan bölgesel ekonomik entegrasyon örgütünün, başvuru sırasında, üyelerinden kendisine hangi yetkilerin devredildiğinin belirtildiği bir yetki bildirisi sunma yükümlülüğ̈̈ (f. 3$)^{88}$; hem örgütün, hem de örgüte üye ülkelerin söz konusu yetkilerde meydana gelebilecek değişiklikleri Konferans Genel Sekreterliğine bildirim yükümlülü̆ğü (f.4) kabul edilmiş, hakkında yetki devrinin yapıldığına ilişkin bildirim yapılmayan konular bakımından ise örgüte üye ülkelerin yetkiye sahip olduklarının varsayılacağ 1 düzenlenmiştir (f.5). Bunun yanı sıra, Konferansa üye olan devletlere, Konferansta tartışmaya açılan özel konular bakımından, bölgesel ekonomik entegrasyon örgütünün yetki sahibi olup olmadığı konusunda gerek örgütten gerekse örgüte üye olan ülkelerden bilgi talep etmek imkânı tanınmıştır (f.6).

AT tarafından Konferans Statüsünün 3. maddesinin 3. fıkrası uyarınca hazırlanan ve 3 Nisan 2007'de Konferansa sunulan yetki bildirisinde, Topluluğun milletlerarası özel hukuk alanında sahip olduğu yetkiye ilişkin belli başlı hususlara yer verilmiş, bir anlamda AT milletlerarası özel hukukunda şu anda geçerli olan durum özetlenmiştir ${ }^{89}$.

Bildiride öncelikle, Topluluğa milletlerarası özel hukuk alanında yetki veren Kurucu Antlaşmanın 61. maddesinin (c ) fikrası ile 65. maddesi açıklanmış $^{90}$, La Haye Konferansının çalışma alanı itibariyle, Topluluğun, söz konusu hükümler uyarınca, özel hukuk alanında adlî işbirliğine ilişkin olmak üzere, sınır aşıcı etkilere sahip ve iç pazarın düzgün işleyişi için gerekli düzenlemeleri yapmak yetkisine sahip olduğu ifade edilmiştir. Ayrıca, Topluluğun La Haye Konvansiyonlarının konusunu teşkil edebilecek olan başka alanlarda da (iç pazar (m. 95) ve tüketicinin korunması (m. 153) gibi) yetkili olduğu belirtilmiştir ${ }^{91}$.

Antlaşmanın 61. maddesinin (c ) bendine dayanılarak kabul edilen milletlerarası özel hukuk alanındaki Topluluk düzenlemeleri, aciz usûllerine $^{92}$, evlilik ve velayete ilişkin hususlarda yargı yetkisi, yarg1

${ }^{87}$ Bkz. FAO Statüsü, m. 2.

${ }^{88}$ La Haye Statüsünde, bölgesel ekonomik entegrasyon örgütlerinden sadece üyeliğe giriş aşamasında Konferansa sunacakları bir yetki bildirisi talep edilmekle yetinilmiş, buna karșın, FAO Statüsünde olduğu gibi, her toplantı öncesinde özel hususlara ilișkin olarak yetki bildirisi sunma yükümlülügüu, pratik olmadığı gerekçesiyle getirilmemiştir. FAO Statüsündeki düzenleme hakkında bkz. FRID, s. 365; SACK, s. 1245.

${ }^{89}$ Declaration of competence of the European Community specifiying the matters in respect of which competence has been transfered to it by its Member States, http://www.hcch.net/index_en.php?act=status.Comment\&csid=992\&disp=rsdn (15.02.2008).

${ }^{90}$ Bildiri, para. 2.

${ }^{91}$ Bildiri, para. 4.

92 1346/2000 sayılı Aciz Usûllerine Dair Konsey Tüzüğü (Council Regulation (EC) No 1346/2000 of 29 May 2000 on insolvency proceedings), O.J. 2000 L 160/1. 
kararlarının tanınması ve tenfizine ${ }^{93}$, hukukî ve ticarî konularda yargı yetkisi, yargı kararlarının tanınması ve tenfizine ${ }^{94}$, nizasız talepler için Avrupa icra emri yaratılmasına ${ }^{95}$, hukukî ve ticarî konularda mahkeme ya da mahkeme dışı organlarca verilen belgelerin üye devletlerde tebliğine ${ }^{96}$, hukukî ve ticarî konularda delil toplanmasında üye devletler arasında işbirliğine ${ }^{97}$ ve adlî yardıma ilişkin asgarî ortak kurallar getirilmesi suretiyle sınır aşan uyuşmazlıklarda adalete erişimin geliştirilmesine ${ }^{98}$ ilişkindir $^{99}$. Ancak tüketicinin korunması, sigorta, malî hizmetler ve fikrî haklar gibi muhtelif konularda çıkarılan Topluluk düzenlemelerinde de milletlerarası özel hukuk kuralları yer alabilmektedir ${ }^{100}$.

Topluluğun milletlerarası özel hukuk alanındaki dış yetkisi konusunda ise, her ne kadar bu alan itibariyle Topluluğun açıkça düzenlenmiş bir dış yetkisi mevcut olmasa da, zımnî dış yetki hakkındaki ATAD içtihadı uyarınca, Kurucu Antlaşmanın 61 (c) ve 65. maddelerinde yer alan hükümlerin, Topluluğa bu alanda dış yetki izafe ettiği kabul edilmiştir. $\mathrm{Bu}$ itibarla, bildiride, Divan'ın 1971 tarihli ERTA ve 2002 tarihli Open Skies ${ }^{101}$ Kararları ile Uluslararası Çalışma Örgütü Anlaşmasının ${ }^{102}$ ve Ren- Moselle

93 2201/2003 sayılı Evlilik ve Velayete İlişkin Hususlarda Yargı Yetkisi, Yargı Kararlarının Tanınması ve Tenfizine Dair Konsey Tüzüğü (Council Regulation (EC) No 2201/2003 of 27 November 2003 concerning jurisdiction and the recognition and enforcement of judgments in matrimonial matters and the matters of parental responsibility), O.J. 2003 L338/1.

94 44/2001 sayılı Hukukî ve Ticarî Konularda Yargı Yetkisi, Yargı Kararlarının Tanınması ve Tenfizine Dair Konsey Tüzüğü (Council Regulation (EC) No 44/2001 of 22 December 2000 on jurisdiction and the recognition and enforcement of judgments in civil and commercial matters), O.J. 2001 L 12/1.

95 805/2004 sayılı Nizasız Talepler İçin Avrupa İcra Emri Yaratılmasına Dair Topluluk Tüzüğü (Regulation (EC) No 805/2004 of the European Parliament and of the Council of 21 April 2004 creating a European Enforcement Order for uncontested claims), O.J. 2004 L 143.

${ }^{96}$ 1348/2000 sayılı Hukukî ve Ticarî Konularda Mahkeme ya da Mahkeme Dışı Organlarca Verilen Belgelerin Üye Devletlerde Tebliğine ilişkin Topluluk Tüzüğü (Council Regulation (EC) No 1348/2000 of 29 May 2000 on the service in the Member States of judicial and extrajudicial documents in civil or commercial matters), O.J. 2000 L 160/37.

${ }^{97}$ 1206/2001 sayılı Hukukî ve Ticarî Konularda Delil Toplanmasında Üye Devletler Arasında İşbirliğine Dair Topluluk Tüzüğü (EC Regulation 1206/2001 on Co-operation between the Courts of the Member States in the Taking of Evidence in Civil or Commercial Matters), O.J. 2001 L174/1.

98 Adlî Yardıma İlişkin Asgarî Ortak Kurallar Getirilmesi Suretiyle Sınır Aşan Uyuşmazlıklarda Adalete Erişimin Geliştirilmesine Dair 27 Ocak 2003 tarihli Konsey Direktifi (Council Directive 2002/8/EC of 27 January 2003 to improve access to justice in cross-border disputes by establishing minimum common rules relating to legal aid for such disputes), O.J. 2003 L 26/41.

${ }^{99}$ Bildiri, para. 5.

${ }^{100}$ Bildiri, para. 5.

${ }^{101}$ Case C- 467198, Commission v. Denmark, ECR 2002, s. 1-9519.

102 Opinion 2/91 on the ILO Convention [1993] ECR I-1061. 
nehirleri üzerinde yapılan taşımacılığın düzenlenmesine ilişkin uluslararası anlaşmanın imzalanmasına ilişkin görüşlerine atıf yapılarak, Topluluğun, "iç yetkinin kullanılarak ortak politikaların uygulanmasina yönelik düzenlemeler yapılmış olması ya da uluslararası anlaşmanın akdinin Topluluk hedeflerinden birine ulaşılması bakımından gerekli olması durumunda" uluslararası anlaşma yapmak bakımından yetkili olduğunun kabul edildiği belirtilmiştir ${ }^{103}$. Bunun yanı sıra, ancak yapılacak uluslararası anlaşmanın Topluluk içi düzenlemeleri etkilemesi ya da kapsamlarını değiştirmesi durumunda, Topluluğun dış yetkisinin münhasır nitelikte olduğunun kabul edilebileceği ve böyle bir durumda sadece Topluluğun üçüncü devletlerle ve uluslararası örgütlerle ilişkilerinde taahhüt altında girebilecek olduğunun altı çizilmiştir. Bu konuda belirtilen son husus, bir uluslararası anlaşmanın tamamen ya da kısmen Topluluğun münhasır yetkisi kapsamında değerlendirilebileceğidir.

Yetki bildirisinde yer verilen bir başka konu, milletlerarası özel hukuk alanı itibariyle özel bir rejime tâbi olan Birleşik Krallık, İrlanda ve Danimarka'nın durumuna ilişkindir. Söz konusu üye devletler bakımından, Amsterdam Antlaşmasına eklenen protokollerde, bu devletlerin Kurucu Antlaşmanın IV. Başlı̆ğ kapsamında yapılacak düzenlemelerle, uluslararası anlaşma hükümleriyle ve ATAD'ın söz konusu düzenleme ve hükümlere ilişkin yorumlarıyla bağlı olmayacakları ve bunların söz konusu üye devletlerde uygulanmayacağı kabul edilmiştir. Söz konusu devletlerden Birleşik Krallık ve İrlanda bakımından, yapacakları bildirimlerle söz konusu başlık altında yapılacak düzenlemelerin gerek kabulü süreçlerine gerekse uygulanmasına katılabilme imkânı ("opt in") kabul edilirken (Birleşik Krallık ve İrlanda'nın durumuna ilişkin protokol, m.1, 3, 4), Danimarka bakımından böyle bir imkân mevcut değildir ${ }^{104}$. Nitekim, Birleşik Krallık ve

\footnotetext{
${ }^{103}$ Bildiri, para. 6.

${ }^{104}$ Her ne kadar bildiride belirtilmemiş olsa dahi, Danimarka'nın durumuna ilişkin bir husus açıklanmalıdır. Danimarka'ya, Birleşik Krallık ve İrlanda'dan farklı olarak Kurucu Antlaşmanın IV. Başlığı altında yapılacak düzenlemelere dair yasama süreçleri ile söz konusu düzenlemelerin uygulanmasına katılabilme imkânı ("opt in") tanınmamış olsa da, Danimarka'nın da Protokolün belli hükümlerinden ya da bütününden yararlanmak istemediğini bildirme imkânı mevcuttur (Danimarka'nın Durumuna ilişkin Protokol, m. 7). Nitekim, Danimarka ile AT arasında 44/2001 sayılı Hukukî ve Ticarî Konularda Yargı Yetkisi, Yargı Kararlarının Tanınması ve Tenfizine Dair Konsey Tüzüğü ile 1348/2000 sayılı Hukukî ve Ticarî Konularda Mahkeme ya da Mahkeme Dışı Organlarca Verilen Belgelerin Üye Devletlerde Tebliğine ilişkin Topluluk Tüzüğü hükümlerinin uygulanabilmesi için taraflar arasında 19 Ekim 2005 tarihinde iki anlaşma imzalanmış ve 1 Temmuz 2007 itibariyle yürürlüğe girmiştir. Anılan anlaşmalar kapsamında, söz konusu tüzükler Danimarka bakımından uluslararası hukuk tasarrufu olarak uygulanmaktadır. Danimarka ile AT arasında imzalanan söz konusu anlaşmalar için bkz. Agreement between the European Community and the Kingdom of Denmark on jurisdiction and the recognition and enforcement of judgements in civil and commercial matters, O.J. 2005 L 299/ 62; Agreement between the European Community and the Kingdom of Denmark on the service
} 
İrlanda, Kurucu Antlaşmanın 61. maddesinin (c) fıkrasına dayanılarak kabul edilmiş ve bildiride belirtilmiş Topluluk tasarruflarına katılmışlardır ${ }^{105}$.

Yetki bildirisinde belirtilen son husus, Topluluğun yetki kazanımının, niteliği itibariyle sürekli bir gelişim içinde olmasıdır. Bu itibarla, Topluluğun yetkisinde bir değişiklik meydana gelmesi durumunda, söz konusu değişiklik derhal, AT ya da üye devletler tarafından Konferans Genel Sekreterliğine bildirilecektir ${ }^{106}$.

\section{2- Üyelik Haklarının Kullanımı}

Üyelik haklarının ne şekilde kullanılacağına dair hüküm, Konferans statüsünün 3. maddesinin 7. fikrasında yer almaktadır. Buna göre, üyelik hakları, bölgesel ekonomik entegrasyon örgütü ile La Haye Konferansına üye olan üyeleri arasında, yetkili oldukları alanlara ilişkin olarak alternatifli olarak kullanılacaktır. Bu hüküm de FAO Statüsünün 2. maddesinin 8. fıkrası esas alınarak düzenlenmiştir.

Bununla birlikte, hangi üyelik haklarının bu hükme dahil olduğu konusunda bir açıklık mevcut değildir. Oy hakkı, aşağıda da belirtileceği gibi aynı maddenin 8. fikrasında yer alan özel hükme tâbidir. Diğer yandan, söz konusu hükmün Konferans toplantılarını da kapsar şekilde düzenlemesine ilişkin öneri, La Haye Konferansı müzakerelerinde farklı görüşlerin ifade edilmesi sebebiyle sahip olunan zenginliğin ve mümkün olduğunca farklı bakış açılarının sergilenmesi gerekliliğinin altı çizilerek, Komisyon toplantılarında ve Statü değişikliklerinin yapıldığı yirminci birleşimde kabul görmemiştir ${ }^{107}$. Bu anlamda, söz konusu hükmün, Konferansın diplomatik toplantıları bakımından değil, ancak Konferans çalışma grupları ile alt komitelere katılım bakımından uygulanabileceği,

of judicial and extrajudicial documents in civil or commercial matters, O.J. 2005 L 300/55. Ayrıca bkz. BAYRAKTAROĞLU ÖZÇELIK, s. 24, dn. 20 vd.

${ }^{105}$ Birleşik Krallık ve İrlanda, Protokolün 3. maddelerine dayanarak, Topluluğun La Haye Konferansına üyeliğine ilişkin kararın kabulüne de katılmışlardır. Ancak, Danimarka bakımından söz konusu imkân mevcut olmadığından, anılan üye devlet, ne Topluluğun $L a$ Haye Konferansına üyeliğine dair Konsey kararı ile ne de söz konusu kararın uygulanması ile bağlıdır. Dolayısıyla Danimarka, La Haye Konferansı kapsamında bağımsız hareket etmek yetkisine sahiptir. Bununla birlikte Danimarka'nın dahi Kurucu Antlaşmanın 10. maddesinde tüm üye devletler bakımından kabul edilen sadakat yükümlülü̆ğü altında olduğu savunulmuştur. Bkz. BARIATTI, S./ RICCI, C.: "The Implications of the Accession of the European Community to the Hague Conference on Private International Law", Briefing Paper, P/C/LIBE/FWC/2005-xx, <http://www.astrid-online.it/--spazio-e/Studi-ric/EP_BriefingPaper_Accession-to-HCCH_final.pdf $>$, s. 6 .

${ }^{106}$ Bildiri, para. 8.

107 HAGUE CONFERENCE ON PRIVATE INTERNATIONAL LAW: "Report of The Special Commission on General Affairs And Policy of the Conference of 31 March / 1 April 2005", Preliminary Document No 32A of May 2005 for the attention of the Twentieth Session 〈http://www.hcch.net/upload/wop/genaff_pd32a_e.pdf> (12.04.2008); SCHULZ, s. 947. 
bununla birlikte uygulamada, söz konusu hükme çok fazla bağlı kalınmayarak Konferans kapsamındaki zenginliğin korunması amacıyla Topluluk ile üye ülkelerin birlikte katılmaları yönünde bir esnekliğin olabileceği ifade edilmiştir ${ }^{108}$.

Oy hakkının düzenlendiği 8. fıkraya göre ise, üye örgüt, katılmaya yetkili olduğu toplantılarda, oy kullanma hakkına sahip olup, sahip olduğu oy sayısı, tartışılan konu bakımından kendisine yetki devreden ve söz konusu toplantıya kayıtlı üye ülkelerin sayısı kadardır. Bu anlamda söz konusu düzenleme Topluluğa üye ülkelerin sayısı kadar oy hakkı veren FAO Statüsünden (m. 2(8)) farklılık arz eder. Bununla birlikte FAO statüsünün 2. maddesinin 10. fıkrası esas alınarak getirilen düzenlemeye göre, oy kullanma hakkının üye örgüt tarafından kullanılması durumunda örgüte üye ülkeler; üye ülkeler tarafından kullanılması durumunda ise üye örgüt bu hakkını kaybedecektir (m. 3(8), son cümle).

Ancak belirtmek gerekir ki, La Haye Konferansı uygulamasında, kararlar mümkün olduğunca mutabakat ile alınmaktadır ${ }^{109}$. Bu durum, Konferans Statüsünün 8. maddesinin 2. fıkrası ile Konferans Statüsündeki değişiklikler uyarınca değiştirilen Usûl Kurallarının 1(A) hükmünde düzenlenmiştir. Statünün anılan hükmüne göre, diplomatik toplantılar ile Genel İşler ve Politika Konseyi ${ }^{110}$ ve Özel Komisyon toplantılarında kararlar mümkün olduğunca mutabakat ile alınacaktır. Bu hükme paralel olarak ise, Usûl Kurallarında, ancak kararların mutabakat halinde alınamadığı durumlarda, istisnaî olarak oy hakkına ilişkin esaslara başvurulacağına yer verilmiştir.

\section{3- Malî Yükümlülükler}

Konferans üyeliğinin malî yükümlülükleri, Statünün 9. maddesinde yer almaktadır. Bu hüküm, Konferansın bütçe giderlerinin Konferans üyeleri arasında bölüştürüleceğini düzenledikten sonra (f.1), üye örgütün, üyelerine ek olarak Konferansın yıllık bütçesine katkıda bulunmayacağını, ancak üyeliğinden kaynaklanan idarî giderlerin karşılanması amacıyla, Konferans tarafından üye örgüte danışılarak belirlenecek meblağı ödemekle yükümlü olacağını hüküm altına almıştır. Bu anlamda Topluluk, sadece, AT koordinasyon toplantıları için kiralanan ek toplantı salonlarının kirası, kırtasiye, iletişim giderleri gibi idarî giderleri ödemekle yükümlüdür ${ }^{111}$.

\footnotetext{
${ }^{108}$ SCHULZ, s. 947.

109 HAGUE CONFERENCE ON PRIVATE INTERNATIONAL LAW, Preliminary Document No. 21B of February 2005, s. 5.

${ }^{110}$ Konferansin yeni Statüsü ile bütün Konferans üyelerinden oluşan "Genel İşler ve Politika Konseyi”, Konferansın işleyişinden sorumlu organ olarak kabul edilmiştir (m. 4 (1)).

111 HAGUE CONFERENCE ON PRIVATE INTERNATIONAL LAW, Preliminary Document No. 21B of February 2005, s. 7; BARIATTI/ RICCI, s. 7; SCHULZ, s. 946.
} 
Ayrıca Genel İşler ve Politika Konseyi ve özel komisyon delegelerinin seyahat ve yaşam giderleri de, temsil edilen üyeler tarafından ödenecektir.

\section{IV- Üyeliğin La Haye Sözleșmeleri Üzerindeki Etkisii ${ }^{112}$}

Topluluk Konferansa üye olması ile birlikte, La Haye Sözleşmelerinden kendi yetkisi kapsamında bulunanlara taraf olmak imkânını kazanmış olmaktadır. AT'nin üyeliği akabinde hazırlanan sözleşmelere tek başına mı, Topluluğa üye ülkelerle birlikte mi taraf olacağı, somut sözleşmenin konu ve kapsamı itibariyle Topluluğun münhasıran yetkili olup olmadığı ile ilgilidir. Sözleşmenin münhasıran Topluluğun yetkili olduğu alanlar bakımından düzenleme getirmesi durumunda, gerek sözleşmenin müzakeresi gerekse akdi bakımından AT'nin tek başına yetkili olması gerekirken ${ }^{113}$; sözleşme bakımından kısmen Topluluğun, kısmense Topluluğa üye ülkelerin yetkili olması durumunda, sözleşmenin karma anlaşma şeklinde Topluluk ve üye devletler tarafından müzakere edilip imzalanması gerekmektedir ${ }^{114}$.

Bu noktada önem taşıyan bir husus, AT'nin Konferansa üyeliği sonrasında hazırlanan La Haye Sözleşmelerinin (ister münhasır yetki ister paylaşımlı yetki alanına dahil olsunlar) Topluluk hukukuna etkisidir. Bu tür sözleşmelerin AT kapsamında Topluluk hukukunun bir parçası olarak uygulanacağına şüphe yoktur. Bununla birlikte, Sözleşmelerin, mevcut Topluluk tasarruflarında yer alandan farklı düzenleme getirmesi durumunda, Topluluğun uluslararası yükümlülüklerini yerine getirmek bakımından, Topluluk hukukunun ilgili hükmünün değiştirilmesi zorunluluğu gündeme gelebilecektir ${ }^{115}$. Bu durum, La Haye Menkul Kıymetler Sözleşmesi ${ }^{116}$ kapsamında gündeme gelmiş ve söz konusu Sözleşmenin imzalanarak, Sözleşme hükümleri ile çelişen Topluluk düzenlemelerinin değiştirilmesi gerekliliği belirtilmiştir. Söz konusu Sözleşmenin hazırlık aşamasında, Topluluk içerisinde yasama süreci devam eden 2002/47/EC sayılı Finansal Teminat Düzenlemeleri Hakkında Direktifin ${ }^{117}$, uygulanacak hukuka ilişkin düzenleme getiren 9. maddesinin, La Haye Menkul Kıymetler Sözleşmesi ile uyumlu olması gerekliliği tespit edilmekle birlikte, Direktifin konusu

112 Topluluğun La Haye Konferansına üyeliğinin, münferit La Haye Sözleşmeleri üzerinde yaratabileceği etkilerin ayrıntılı ve kapsamlı olarak incelenmesi, bu çalışmanın kapsamını aşacak nitelikte olduğundan, burada, belli başlı tespitler yapılmakla yetinilecektir.

113 Ancak Danimarka'nın Kurucu Antlaşmanın IV. Başlığına ilişkin olarak tâbi olduğu özel rejim dikkate alınarak, somut La Haye Sözleşmesi bakımından Topluluğun yetkisinin söz konusu başlık altında yer alan $61 \mathrm{vd}$. maddelerden kaynaklanması durumunda, söz konusu üye ülkenin, bağımsız olarak hareket etme yetkisinin bulunduğu hatırlanmalıdır.

114 BARIATTI/ RICCI, s. 8. Karma anlaşmalar (mixed agreements) hakkında bkz. MACLEOD/ HENDRY/ HYETT, s. 142 vd.

115 BARIATTI/ RICCI, s. 8; POCAR, s. 128-129.

${ }^{116} \mathrm{Bu}$ sözleşme, her ne kadar AT'nin La Haye Konferansına üyeliği öncesinde de hazırlanmış olsa, yukarıda da ifade edildiği gibi, Topluluğun katılımına imkân sağlamıştır.

${ }^{117}$ Directive 2002/47/EC of the European Parliament and of the Council of 6 June 2002 on financial collateral arrangements, O.J. 2002 L 168/43. 
bakımından acil bir Topluluk düzenlemesine duyulan ihtiyaç sebebiyle direktif kabul edilmiş; ancak, AB Konseyi tarafından söz konusu La Haye Sözleşmesinin tamamlanması ile birlikte, her iki düzenleme arasında paralellik sağlanması amacıyla Direktifin 9. maddesinin yeniden gözden geçirilmesinin de gündeme gelebileceği belirtilmiştir ${ }^{118}$. Keza, Menkul Kıymetler Sözleşmesi hakkında Avrupa Komisyonu tarafından yapılan tahlilde de, anılan Sözleşmenin imzalanmasının Topluluğun menfaatine bir durum teşkil ettiği, ancak Sözleşmenin Topluluk tarafından onaylanması aşamasında Sözleşme hükümleri ile çelişen direktif hükümlerinin de değiştirilmesi gerektiği üzerinde durulmuştur ${ }^{119}$. Benzer şekilde, söz konusu Sözleşmenin Topluluk tarafından imzalanması halinde 98/26/EC sayılı Mutabakat Kesinliği Direktifi ${ }^{120}$ ile 2001/24/EC sayılı Kredi Kurumlarının Yeniden Yapılandırılmasına ve Tasfiyesine İlişkin Direktifin ${ }^{121}$ hükümlerinin de Sözleşmeye uygun olarak değiştirilmesi gerekliliği ifade edilmiştir ${ }^{122}$.

Bunun yanı sıra, Menkul Kıymetler Sözleşmesi ile birlikte Yetkili Mahkeme Seçimine Dair Sözleşme, yukarıda da ifade edildiği gibi Topluluğun La Haye Konferansına üyeliğinin öncesinde hazırlanmış olmakla birlikte, bölgesel ekonomik entegrasyon örgütlerinin de katılımına dair hükümlere yer vermiş ve bu şekilde Topluluğun taraf olmasına imkân tanımıştır. Bu iki Sözleşmeye taraf olunması konusunda da, Sözleşmelerin konu ve kapsamları itibariyle, Topluluk ve/veya üye ülkelerin yetkisi kapsamında bulunmaları belirleyici olacaktır. Özellikle Yetkili Mahkeme Seçimine Dair Sözleşme, konusu itibariyle Divan'ın yeni Lugano Konvansiyonunun Topluluk tarafından akdine ilişkin açıladığı görüşün etkilerine dair tartışmaları akla getirmektedir. Divan'ın bu görüşündeki yorumu hatırlanacak olursa, Brüksel I Tüzüğünün yarg1 yetkisi, yarg1 kararlarının tanınması ve tenfizi konusunda, yeknesak ve tutarlı bir sistemi oluşturduğunu, tarafları arasında benzer bir sistem yaratmayı amaçlayan bir uluslararası anlaşmanın ise, Topluluk hukuku kurallarının uyumlu ve tutarlı olarak uygulanmasını ve bu kuralların kurduğu sistemin düzgün işleyişini etkileyebileceğinin tespit edilmesi durumunda, Topluluğun söz konusu sözleşmenin akdi konusunda münhasıran yetkili olacağını ifade etmişti.

${ }^{118}$ Common Position (EC) No 32/2002 adopted by the Council on 5 March 2002 with a view to adopting Directive 2002/. . .EC of the European Parliament and of the Council of . . . on financial collateral arrangements, O.J. 2002 C 119 E/03.

119 EUROPEAN COMMISSION: Frequently Asked Questions on the Hague Securities Convention: Commission Legal Assessment, MEMO/06/267, s. 3.

${ }^{120}$ Directive 98/26/EC of the European Parliament and of the Council on settlement finality in payment and securities settlement systems, O.J. 1998 L 166/45.

${ }^{121}$ Directive 2001/24/EC of the European Parliament and of the Council of 4 April 2001 on the reorganisation and winding up of credit institutions, O.J. $2001 \mathrm{~L} \mathrm{125/15.}$

${ }^{122}$ Proposal for a Council Decision Concerning the signing of the Hague Convention on the Law applicable to certain rights in respect of securities held with an intermediary, COM (2003) 783 FINAL, s. 4. 
Divanın bu görüşündeki yaklaşımından hareket edilerek, Yetkili Mahkeme Seçimine Dair La Haye Sözleşmesinin imzalanması aşamasında sözleşmenin Brüksel I Tüzügünü etkileyebileceği sonucuna varılması, dolayısıyla Topluluğun münhasıran yetkili olduğunun kabul edilmesi mümkündür ${ }^{123}$.

Bütün bunlardan farklı olarak belirtilmesi gereken bir husus da, Topluluğun, La Haye Konferansına üyeliği öncesinde hazırlanmış olan ve bölgesel ekonomik entegrasyon örgütlerinin taraf olmasına ilişkin özel hüküm bulunmayan La Haye Sözleşmelerine taraf olup olamayacağıdır. Mevcut durumda söz konusu sözleşmeler, sadece devletlerin katılımına imkân sağlamaktadır. Bu duruma ilişkin olarak, Topluluğun La Haye Konferansına üyeliği aşamasında sunduğu bir bildiri mevcuttur ${ }^{124}$. Burada Topluluk, "mevcut La Haye Sözleşmelerine katılımı bakımından Topluluk menfaatinin bulunup bulunmadığının tespit edilerek, söz konusu menfaatin mevcut olması durumunda, bu sözleşmelerde bölgesel ekonomik entegrasyon örgütlerinin katılımını öngören hükümlerin olmayışından kaynaklanan zorlukların aşılması amacıyla La Haye Konferansıyla işbirliği içerisinde hareket edileceğini" ifade etmiştir ${ }^{125}$. Bununla birlikte, Topluluk tarafından La Haye Sözleşmelerine katılım bakımından bir menfaatin tespit edilmesi durumunda, sözleşmelere taraf olunmasındaki zorluğun ne şekilde aşılabileceği belirsizdir. Bu konuda La Haye Konferansı tarafından getirilen öneri, her ne kadar zaman alacaksa da söz konusu sözleşmeler bakımından protokollerin kabul edilerek bölgesel ekonomik entegrasyon örgütlerinin de bu sözleşmeleri imzalayıp onaylamasına imkân sağlanmasıdır ${ }^{126}$. Bu konuda üyeliği öncesinde Topluluk tarafından benimsenen yaklaşım ise, Konferansın önerisinden farklı olmuştur. 1996 tarihli Velayet ve Çocukların Korunmasına Dair Önlemlere ilişkin Mahkemelerin Yetkisi, Uygulanacak Hukuk, Tanıma, Tenfiz ve İşbirliği Hakkındaki La Haye Sözleşmesinin ${ }^{127}$

${ }^{123}$ Bkz. SCHULZ, s. 942, dn. 16; BARIATTI/ RICCI, s. 9; BOGDAN, s. 13. Bu görüş, Lugano Görüşünden önce dahi, La Haye Yetkili Mahkeme Seçimine Dair Sözleşmenin temelini teşkil eden Medenî ve Ticarî Konularda Yargı Yetkisi, Yargı Kararlarının Tanınması ve Tenfizine Dair La Haye Sözleşmesinin hazırlanması aşamasında da sıklıkla dile getirilmişti: Bkz. TRAEST, s. 225; BOELE-WOELKI/ VAN OOIK, s. 23; KOTUBY, C.T.: "External Competence of the European Community in the Hague Conference of Private International Law: Community Harmonization and Worldwide Unification", NILR, Y.2001, Vol. XLVIII, I. 1, s. 1-30.

${ }^{124}$ Bkz. Declaration by the Community on certain matters concerning the Hague Conference on Private International Law. Söz konusu bildiri, Topluluğun La Haye üyeliği konusundaki AB Konseyi kararının eklerinden biri olarak sunulmuştur. Bkz. yuk. dn. 33.

${ }^{125} \mathrm{Bu}$ bildiriye dayanılarak Topluluğa La Haye Sözleşmelerine katılımı konusunda yardımcı olmak amacıyla La Haye Konferansı Genel Sekreteri tarafından söz konusu Sözleşmelerin kapsam ve içeriklerini açıklamak amacıyla bir bilgi notu hazırlanmıştır. Söz konusu bilgi notu için bkz. yuk. dn. 58 .

${ }^{126}$ Bkz. HAGUE CONFERENCE ON PRIVATE INTERNATIONAL LAW, Preliminary Document No. 14 of June 2001, s. 8.

127 Convention of 19 October 1996 on Jurisdiction, Applicable Law, Recognition, Enforcement and Co-operation in respect of Parental Responsibility and Measures for the 
imzalanması konusunda, AB Konseyi tarafından 2002 yılında alınan bir karar ile, AT üyesi ülkeler, söz konusu Sözleşmenin Topluluğun menfaati uyarınca imzalanması konusunda yetkilendirilmiştir ${ }^{128}$. Bu kararın giriş kısmında, söz konusu Sözleşmenin, uluslararası seviyede çocukların korunmasına dair sağladığı katkı dolayısıyla mümkün olan en kısa sürede Sözleşme hükümlerinin uygulamaya konması gerektiği belirtildikten sonra, söz konusu Sözleşmenin bazı hükümlerinin özellikle Evlilik ile İlgili Meselelerde Yargı Yetkisi ve Yargı Kararlarının Tanınması ve Tenfizine dair 1347/2000 sayılı Konsey Tüzüğ̈̈ ${ }^{129}$ olmak üzere mahkemelerin yetkisi, yarg1 kararlarının tanınması ve tenfizi konusundaki Topluluk düzenlemelerini "etkilediği" ifade edilmiş; bu durumun bir sonucu olarak ise, Sözleşmenin, bu alanda mevcut Topluluk düzenlemelerini etkileyen hükümleri bakımından AT'nin münhasıran yetkili olduğu, AT üyesi ülkelerin ise Sözleşmenin diğer hükümleri bakımından yetkisinin devam ettiğini belirtilmiştir. Ancak, Sözleşmenin sadece devletlerin imzasına açık olmasından hareketle, Topluluğun sözleşmeyi imzalaması, katılması ya da onaylaması mümkün değildir. Söz konusu karara dayanılarak Sözleşme, (1997 yılında imzalayan Hollanda dışındaki) üye ülkeler tarafından 1 Nisan 2003 'te imzalanmıştır ${ }^{130}$. Aynı sözleşmenin onaylanması konusunda da, Komisyon yine bir AB Konsey kararı alınması yönünde öneri sunmuşs ${ }^{131}$, ancak Sözleşmenin Cebelitarık'da uygulanması konusunda Birleşik Krallık ile İspanya arasında çıkan anlaşmazlık sebebiyle henüz, Konsey kararı kabul edilememiş, dolayısıyla da Sözleşme AT üyeleri tarafından onaylanamamıştır.

Protection of Children. Sözleşme metni için bkz. <http://www.hcch.net/index_en.php?act $=$ conventions.text\&cid=70> (05.04.2008).

${ }^{128}$ Council Decision of 19 December 2002 authorising the Member States, in the interest of the Community, to sign the 1996 Hague Convention on Jurisdiction, Applicable Law, Recognition, Enforcement and Cooperation in respect of Parental Responsibility and Measures for the Protection of Children, O.J. 2003 L 48/1. Ayrica bkz. BOELE-WOELKI/ VAN OOIK, s. 22, BOGDAN, s. 13.

129 Council Regulation (EC) No 1347/2000 of 29 May 2000 on jurisdiction and the recognition and enforcement of judgments in matrimonial matters and in matters of parental responsibility for children of both spouses, O.J. 2000 L 160/19.

${ }^{130}$ Danimarka, Amsterdam Antlaşmasına eklenen Protokol hükümleri uyarınca, Antlaşmanın IV. Başlığı altında yapılacak düzenlemelerle bağlı değildir. Dolayısıyla, 1996 tarihli $L a$ Haye Sözleşmesinin üye devletlerce imzalanmasına ilişkin Konsey kararı, Danimarka dışındaki üye ülkeleri kapsamaktadır. Danimarka, bu sözleşmeyi imzalamak konusunda bağımsız hareket etmiş, ancak sözleşmeyi diğer AT üyesi ülkelerle birlikte 1 Nisan 2003’te imzalamıştır.

${ }^{131}$ Proposal for a Council Decision authorising the Member States to ratify or accede to, in the interest of the European Community the Convention on Jurisdiction, Applicable Law, Recognition, Enforcement and Co-operation in respect of Parental Responsibility and Measures for the Protection of Children (1996 Hague Convention), <http://eurlex.europa.eu/smartapi/cgi/sga_doc?smartapi!celexplus!prod!DocNumber\&lg=en\&type_do c=COMfinal\&an_doc=2003\&nu_doc $=348>(05.04 .2008)$. 


\section{V-SONUÇ}

AT’nin La Haye Konferansına üyeliği, en azından ilk bakışta iki örgüt açısından da önemli bir gelişmeyi ifade etmektedir. Söz konusu üyelik, Topluluğun milletlerarası özel hukuk alanında sahip olduğu dış yetkisinin kullanılması anlamına gelir. Topluluk bu şekilde, milletlerarası özel hukukun yeknesaklaştırılması amacına hizmet eden en önemli uluslararası örgütlerden birinde resmen söz sahibi olmakta; Amsterdam Antlaşması ile birlikte, milletlerarası özel hukuk alanında yetki kazanmış olmasına rağmen, Konferans içerisinde gözlemci statüsünde bulunarak söz konusu yetkisini kullanamaması sebebiyle oluşan durum ortadan kalkmış olmaktadır. $L a$ Haye Konferansı bakımından ise, söz konusu üyelik, her şeyden önce 50 yıldan fazla bir geçmişe sahip Konferans Statüsünün değiştirilmesi ve bu şekilde devletlerin yanı sıra, uluslararası örgütlerin de üyeliğine imkân tanınmasına sebep olması bakımından önemlidir.

Ancak kuşkusuz, Topluluğun, La Haye Konferansına tam katılımının başarılı sonuçlar verip vermeyeceği, zamana ve özellikle de La Haye Sözleşmelerinin Topluluk tarafından imzalanıp uygulanmasına bağlıdır. Bu anlamda, Topluluk tarafından söz konusu sözleşmelerin gerek hazırlık gerekse müzakere süreçlerine aktif olarak katılınması ve sonrasında da sözleşmelerin imzalanıp onaylanarak yürürlüğe konması önem arz eder. Ancak bu şekilde gerçek anlamda milletlerarası özel hukuk kurallarının bölgesel ve uluslararası alanda uyumlaştırılmasında paralellik sağlanmasına hizmet edilebilecek; özellikle Amsterdam Antlaşması ile birlikte, Topluluğun milletlerarası özel hukukta yetkili sayılmasının, La Haye Konferansı bakımından bir tehlike teşkil etmediği, aksine, uluslararası yeknesaklaştırma çalışmalarına katkıda bulunacağı teyid edilecektir. Diğer yandan, La Haye Konferansı bakımından Topluluğun üyeliğinin olumlu sonuçlar verebilmesinin bir diğer şartı ise, Konferans gündemini işgal eden konular bakımından, yetkinin Topluluk ile Topluluğa üye ülkeler arasında ne şekilde paylaşıldığının mümkün olduğunca kısa sürede tespit edilerek, buna bağlı olarak üyelik haklarının kullanımıdır. Zira, aksine bir durum, Konferans faaliyetlerini önemli ölçüde sekteye uğratma tehlikesini barındırmaktadır. 


\section{KAYNAKÇA}

BARIATTI, S./ RICCI, C.: "The Implications of the Accession of the European Community to the Hague Conference on Private International Law", Briefing Paper, P/C/LIBE/FWC/2005-xx, <http://www.astridonline.it/--spazio-e/Studi--ric/EP_BriefingPaper_Accession-to$\mathrm{HCCH}$ _final.pdf $>$.

BASEDOW, J.: "The Communitarization of the Conflict of Laws Under the Treaty of Amsterdam", CMLR, Y. 2000, Vol. 37, s. 687-708.

BAYRAKTAROĞLU ÖZÇELIK, G.: Avrupa Topluluğunun Milletlerarası Özel Hukuk Alanında Uluslararası Anlaşma Akdetme Yetkisi ve C01/03 sayılı ve 7 Şubat 2006 Tarihli Avrupa Toplulukları Adalet Divanı Görüşü, AÜHFD, Y. 2008, C. 57, S. 2, s. 17- 49.

BAYRAKTAROĞLU, G.: "Harmonization of Private International Law At Different Levels: Communitarization v. International Harmonization", EJLR, Y. 2004, Vol. 5, I. 1/ 2, s. 127-173.

BAUMÉ, T.: "Competence of the Community to Conclude the New Lugano Convention on Jurisdiction and Recognition and Enforcement of Judgements in Civil and Commercial Matters: Opinion 1/03 of 7 Feburary 2006", German Law Journal, Y. 2006, Vol. 7, I. 8, s. 681-692.

BETLEM, G./ HONDIUS, E.: "European Private Law after the Treaty of Amsterdam", ERPL, Y. 2001, Vol. 1, s. 3-20.

BOELE-WOELKI, K./ VAN OOIK, R. H.: "The Communitarization of Private International Law", YPIL, Y. 2002, Vol. 4, s. 1-36.

BOGDAN, M.: Concise Introduction to EU Private International Law, Groningen 2006.

BORRÁS, A.: "Competence of the Community to Conclude the Revised Lugano Convention on Jurisdiction and the Recognition and Enforcement of Judgments in Civil and Commercial Matters- Opinion C-1/03 of February 2006: Comments and Immediate Consequences", YPIL, Y. 2006, Vol. 8, s. 37-52.

CRAIG, P./DE BÚRCA, G.: EU Law (Text, Cases and Materials), Oxford 2007.

ÇİÇEKLİ, B.:”Avrupa Birliğinde Özel Hukukta Adlî İşbirliği ve Mahkeme Kararlarının Serbest Dolaşımı", <http://www.turkaydanismanlik.com/ tr/docs/Avrupa_birliginde_ozel_hukukta_adli_isbirligi_ve_kararlarin_s erbest_dolasimi.pdf> (13.01.2008).

EECHOUT, P: External Relations of the European Union- Legal and Constitutional Foundations, Oxford 2006. 
EKŞİ, N.: Sözleşmeden Doğan Borçlara Uygulanacak Hukuk Hakkında Roma Konvansiyonu, İstanbul 2004.

FRID, R.: The Relations Between the EC and International OrganisationsLegal Theory and Practice, The Hague, London, Boston 1995.

GOVAERE, I./ CAPIAU, J./ VERMEERSCH, A.: "In- Between Seats: The Participation of the European Union in International Organizations", EFAR, Y. 2004, Vol. 9, s. 155- 187.

HARTLEY, T. C.: The Foundations of European Community Law, 6. Ed., Oxford 2007.

KOTUBY, C.T.: "External Competence of the European Community in the Hague Conference of Private International Law: Community Harmonization and Worldwide Unification", NILR, Y.2001, Vol. XLVIII, I. 1, s. 1-30.

KRUGER, T.: "Opinion 1/03, Competence of the Community to Conclude the New Lugano Convention on the Jurisdiction and the Recognition and Enforcement of Judgements in Civil and Commercial Matters", Columbia Journal of European Law, Y. 2006-2007, Vol. 13, s. 189-204.

KRUGER, T.: "Current Developments- Private International Law: The 20th Session of the Hague Conference: A New Choice of Court Convention and the Issue of EC Membership", ICLQ, Y. 2006, Vol. 55, s. 447- 456.

LAVRANOS, N.: "Case Law: Opinion 1/03", CMLR, Y. 2006, Vol. 43, s. 1087- 1100.

LEAL-ARCAS, R.: "Polycephalous Anatomy of the EC in the WTO: An Analysis of Law and Practice", FJIL, Y. 2007, Vol. 19, s. 570-670.

MACLEOD, I./ HENDRY, I. D./ HYETT, S.: The External Relations of the European Communities, Oxford 1996.

OKUTAN, G.: “Topluluğun ve Üye Ülkelerin Yetki Alanlarının Belirlenmesi”, Avrupa Birliği Hukuku (Gülören TEKİNALP/ Ünal TEKINALP), İstanbul 2000, s.77-102.

POCAR, F. (ed.): The External Competence of the European Union and Private International Law, Proceedings of the Round Table held at Milan University on 16 September 2006, Milan 2007.

REMIEN, O.: "European Private International Law, The European Community and Its Emerging Area of Freedom, Security and Justice", CMLR, Y. 2001, Vol. 38, s. 53-86.

SACK, J.: “The European Community's Membership of International Organizations", CMLR, Y. 1995, Vol. 32, s. 1224- 1257. 
SCHULZ, A.: "Current Developments: The Accession of the European Community to the Hague Conference on Private International Law", ICLQ, Y. 2007, Vol. 56, s. 939-950.

TRAEST, M.: "Development of a European Private International Law and the Hague Conference", YPIL, Y. 2003, Vol. 5, s. 223-259.

VAN LOON, H.: "Globalisation and the Hague Conference on Private International Law", International Law FORUM du droit international, Y. 2000, Vol. 2, s. 230-234.

VERWEY, D. R.: The European Community, The European Union and International Law of Treaties, Leiden 2004.

\section{TEMEL RESMÎ METINLER}

Proposal for a Council Decision on the accession of the European Community to the Hague Conference on Private International Law, $\mathrm{COM} / 2005 / 0639$ final.

European Parliament legislative resolution on the proposal for a Council decision on the accession of the European Community to the Hague Conference on Private International Law, P6_TA(2006)0345.

Council Decision of 5 October 2006 on the accession of the Community to the Hague Conference on Private International Law, O.J. 2006 L 297/1.

The Hague Programme: strengthening freedom, security and justice in the European Union, <http://ec.europa.eu/justice_home/doc_centre/doc/ hague_programme_en.pdf> (01.04.2008).

Commission Communication: A strategy on the external dimension of the area of freedom, security and justice, $\operatorname{COM(2005)~} 491$ final.

Communication from the Commission to the Council and the European Parliament - The Hague Programme: Ten priorities for the next five years The Partnership for European renewal in the field of Freedom, Security and Justice, COM/2005/0184 final.

Note from the Council of the European Union, 11 April 2006, 8140/06 LIMITE JUSTCIV 93.

Declaration of competence of the European Community specifiying the matters in respect of which competence has been transfered to it by its Member States, <http://www.hcch.net/index_en.php?act=status. comment \&csid=992\&disp=rsdn $>(15.02 .2008)$.

Statute of the Hague Conference on Private International Law, <http://www.hcch.net/index_en.php?act=conventions.pdf\&cid=29> (11.04.2008). 
HAGUE CONFERENCE ON PRIVATE INTERNATIONAL LAW: "Examination by the European Community of Existing Hague Conventions- Note Drawn up by the Secretary General of the Hague Conference of Private International Law", <www.hcch.net> (15.02.2008).

HAGUE CONFERENCE ON PRIVATE INTERNATIONAL LAW: "Note on the Impact of Regional Integration, in Particular within the European Union, on the Hague Conference and the Hague Conventions", Preliminary Document No. 14 of June 2001, <http://www.hcch.net/upload/wop/genaff2001_pd14e.pdf> (02.04.2008) (Preliminary Document No. 14 of June 2001).

HAGUE CONFERENCE ON PRIVATE INTERNATIONAL LAW: "Note on the Admission of the European Community to the Hague Conference on Private International Law", Update to Preliminary Document No. 13 of February 2004, <http://www.hcch.net/upload/wop/genaff _pd20e.pdf> (02.04.2008) (Update to Preliminary Document No. 13 of February 2004).

HAGUE CONFERENCE ON PRIVATE INTERNATIONAL LAW: Draft Recommendation to the Twentieth Session of the Hague Conference on Private International Law on the admission of the European Community, Preliminary Document No. 21A of February 2005, <http://www.hcch.net/upload/wop/genaff_pd21ae.pdf > (02.04.2008).

HAGUE CONFERENCE ON PRIVATE INTERNATIONAL LAW: Draft Recommendation to the Twentieth Session of the Hague Conference on Private International Law on the admission of the European Community, Preliminary Document No. 21B of February 2005, <http://www.hcch.net/upload/wop/genaff_pd21be.pdf> (02.04.2008) (Preliminary Document No. 21B of February 2005).

HAGUE CONFERENCE ON PRIVATE INTERNATIONAL LAW: Twentieth Session- Final Act, 30th June 2005, <http://www.hcch.net/ upload/finalact20e.pdf>, (11.04.2008).

HAGUE CONFERENCE ON PRIVATE INTERNATIONAL LAW: "Report of The Special Commission on General Affairs And Policy of the Conference of 31 March / 1 April 2005", Preliminary Document No 32A of May 2005 for the attention of the Twentieth Session <http://www.hcch.net/upload/wop/genaff_pd32a_e.pdf> (12.04.2008). 
